\title{
Phytoplankton community dynamics during late spring coccolithophore blooms at the continental margin of the Celtic Sea (North East Atlantic, 2006-2008)
}

\author{
Nicolas Van Oostende ${ }^{\mathrm{a}, *}$, Jérôme Harlay ${ }^{\mathrm{b}, 1}{ }$, Bart Vanelslander ${ }^{\mathrm{a}}$, Lei Chou ${ }^{\mathrm{b}}$, Wim Vyverman ${ }^{\mathrm{a}}$, Koen Sabbe ${ }^{\mathrm{a}}$ \\ ${ }^{a}$ Research Group Protistology and Aquatic Ecology, Department of Biology, Ghent University, Krijgslaan 281-S8, B-9000 Gent, Belgium \\ ${ }^{\mathrm{b}}$ Laboratoire d'Océanographie Chimique et Géochimie des Eaux, Université Libre de Bruxelles, Campus de la Plaine, CP 208, Boulevard du Triomphe, B-1050 Brussels, Belgium
}

\section{A R T I C L E I N F O}

\section{Article history:}

Received 31 October 2011

Received in revised form 9 March 2012

Accepted 23 April 2012

Available online 3 May 2012

\begin{abstract}
A B S T R A C T
We determined the spatial and temporal dynamics of major phytoplankton groups in relation to biogeochemical and physical variables during the late spring coccolithophore blooms (May-June) along and across the continental margin in the Celtic Sea (2006-2008). Photosynthetic biomass (chl $a$ ) of the dominant plankton groups was determined by CHEMTAX analysis of chromatographic (HPLC) pigment signatures.

Phytoplankton standing stock biomass varied substantially between and during the campaigns (areal chl $a\left[\mathrm{mg} \mathrm{chl} a \mathrm{~m}^{-2}\right]$ in June 2006: $63.8 \pm 26.5$, May 2007: $27.9 \pm 8.4$, and May 2008: $41.3 \pm 21.8$ ), reflecting the different prevailing conditions of weather, irradiance, and sea surface temperature between the campaigns. Coccolithophores, represented mainly by Emiliania huxleyi, and diatoms were the dominant phytoplankton groups, with a maximal contribution of, respectively, $72 \%$ and $89 \%$ of the total chl $a$. Prasinophytes, dinoflagellates, and chrysophytes often co-occurred during coccolithophorid blooms, while diatoms dominated the phytoplankton biomass independently of the biomass of other groups. The location of the stations on the shelf or on the slope side of the continental margin did not influence the biomass and the composition of the phytoplankton community despite significantly stronger water column stratification and lower nutrient concentrations on the shelf. The alternation between diatom and coccolithophorid blooms of similar biomass, following the mostly diatom-dominated main spring bloom, was partly driven by changes in nutrient stoichiometry $(\mathrm{N}: \mathrm{P}$ and $\mathrm{dSi}: \mathrm{N})$. High concentrations of transparent exopolymer particles (TEP) were associated with stratified, coccolithophore-rich water masses, which probably originated from the slope of the continental margin and warmed during advection onto the shelf. Although we did not determine the proportion of export production attributed to phytoplankton groups, the abundance of coccolithophores, together with TEP and coccoliths may affect the carbon export efficiency through increased sinking rates of particles formed by aggregation of TEP and coccoliths.
\end{abstract} (c) 2012 Elsevier Ltd. All rights reserved.

\section{Introduction}

Continental shelves and margins are areas of high primary productivity and carbon export and, as such, play a key role in global biogeochemical cycles and ecosystems (Joint et al., 2001; Sharples et al., 2009). Spring phytoplankton blooms are a prominent seasonal feature of the North East Atlantic Ocean (NE Atlantic) (Henson et al., 2006) and are characterised by an intense diatom bloom followed by nanoplankton (among others: prymnesiophytes, prasinophytes and cyanobacteria) when first dissolved silicate and

\footnotetext{
* Corresponding author. Present address: Department of Geosciences, Guyot Hall, Princeton University, Princeton, New Jersey 08544, USA. Tel.: +1 609258 1052; fax: +16092585242.

E-mail address: oostende@princeton.edu (N. Van Oostende).

1 Present address: Chemical Oceanography Unit, Department of Astrophysics Geophysics and Oceanography AGO, University of Liège, Institut de Physique (B5), B-4000 Sart Tilman, Belgium.
}

then other nutrients become depleted, and increasing water column stratification hinders nutrient replenishment to the euphotic zone (Joint et al., 1986; Lochte et al., 1993; Rees et al., 1999; Raitsos et al., 2006; Leblanc et al., 2009). Especially, coccolithophores are a prominent feature of the late spring bloom, and this has been attributed to their tolerance for high irradiances, lower nutrient requirements and/or ability to utilise organic nitrogen or phosphorus sources (Palenik and Henson, 1997; Leblanc et al., 2009 and references therein). Bloom termination follows when nutrient depletion depresses primary productivity and grazing and viral control catch up with algal growth (Brussaard, 2004; Calbet and Landry, 2004; Behrenfeld, 2010). In reality, this general NE Atlantic spring bloom scenario can be more or less scrambled due to local weather conditions and physical phenomena (Ji et al., 2010), both in the open ocean, where movements of eddies and other water masses can reset succession events (Smythe-Wright et al., 2010), and along continental margins, where vertical mixing resulting from internal tides can bring nutrient-rich deeper water 
into the euphotic zone (Sharples et al., 2007). Along the continental margin of the Bay of Biscay and the Celtic Sea, phytoplankton growth, and coccolithophorid blooms in particular, have been shown to be triggered and/or sustained by internal tidal wave formation at the shelf break leading to enhanced vertical mixing and the injection of inorganic nutrients to the surface waters (Holligan and Groom, 1986; Lampert et al., 2002; Sharples et al., 2009; Harlay et al., 2010).

A general scenario of late spring bloom evolution at the continental margin of the northern Bay of Biscay is proposed by Harlay et al. (2010): when the main diatom spring bloom (mid April) has depleted dissolved silicate ( $\mathrm{dSi}$ ) to levels below $2 \mu \mathrm{mol} \mathrm{l}^{-1}$, vertical inputs of nutrients along the shelf break trigger mixed blooms mainly dominated by coccolithophores. We consider blooms of coccolithophores to be a sequence of events when their biomass constitutes a significant portion of the total phytoplankton community, enabling them to influence local biogeochemistry and trophodynamics (Smayda, 1997). These blooms further exhaust nutrients as the water column stratifies and the water mass is advected over the continental shelf, following the general residual circulation in the area (Pingree and Lecann, 1989; Huthnance et al., 2001; Suykens et al., 2010), while dinoflagellates, chrysophytes, prasinophytes and cryptophytes can become increasingly more important. This succession leads to the appearance of high reflectance (HR) patches which are associated with the dissipative stage of coccolithophorid blooms (of Emiliania huxleyi in particular), when coccoliths are shed into the water column, affecting the albedo of the surface water (Westbroek et al., 1993; Harlay et al., 2010). This bloom succession considerably alters the biogeochemical characteristics of their environment through biogenic calcification and the release of transparent exopolymer particles (TEP), which affect carbon export through mineral ballasting and aggregation (Armstrong et al., 2002; Engel et al., 2004; De La Rocha and Passow, 2007), and dimethyl sulphide production, which introduces sulphur into the atmosphere (Burkill et al., 2002; Stefels et al., 2007; Seymour et al., 2010).

While the annual occurrence of extensive coccolithophore blooms in late spring in the NE Atlantic is well-documented (Leblanc et al., 2009 and references therein), there is no consensus on the factors triggering coccolithophorid blooms and modulating the turnover time of the calcite they produce (Lessard et al., 2005; Poulton et al., 2007, 2010; Boyd et al., 2010). Changes in environmental control factors such as light intensity, water column stability, temperature, $\mathrm{CO}_{2}$ concentration, nitrate and phosphate levels and their ratio, and the concentration trace metals (e.g. Fe, $\mathrm{Zn}$, and $\mathrm{Mn}$ ) have been shown to influence coccolithophore physiology and control phytoplankton community assemblage to various extents (Nanninga and Tyrrell, 1996; Zondervan, 2007; Boyd et al., 2010, and references therein). However, only few studies have described the structure and the spatial and temporal dynamics of phytoplankton communities during these blooms along the western European continental margin (Head et al., 1998; Joint et al., 2001; Fileman et al., 2002; Lampert et al., 2002). This information is needed, as the importance of the phytoplankton community structure to the biological pump is still poorly understood (Smythe-Wright et al., 2010, and references therein). Changes in the community composition are expected to impact primary and export production, and as such food web structure and dynamics, as well the biogeochemical cycling of carbon and other bio-limiting elements in the sea (Guidi et al., 2009; Finkel et al., 2010).

We investigated the dynamics of the main phytoplankton groups during three campaigns (2006-2008) in late spring (MayJune, i.e. after the main diatom bloom in April), along and across the continental margin of the Celtic Sea. More specifically, we investigated if (1) water column properties such as stratification, nutrient levels and the ratios differed between the shelf and the slope side of the continental margin, (2) how changes in such physical and biogeochemical variables influence the phytoplankton community structure and biomass, and (3) how phytoplankton biomass and community structure are related to the standing stocks of particulate organic carbon (POC), TEP, and particulate inorganic carbon (PIC; calcite). We assessed the phytoplankton community structure using a chemotaxonomic (pigment-based) approach and its dynamics and relation to biogeochemical variables analysed using multivariate non-parametric analyses.

\section{Materials and methods}

\subsection{Study area and general set-up of the campaigns}

The study area along the continental margin of the northern Bay of Biscay, on the shelf of the Celtic Sea included the La Chapelle Bank (LC), the Meriadzek Terrace (M), the Goban Spur (GS) area, and one station on the Armorican shelf (Fig. 1 and Table 1). Three campaigns were carried out from the 31st of May to the 9th of June 2006 , from the 10th to the 24th of May 2007, and from the 7th to the 23rd of May 2008, onboard RV Belgica. Eighteen stations were located in the vicinity of the La Chapelle Bank $\left(47^{\circ} \mathrm{N}, 8^{\circ} \mathrm{W}\right)$ while eight stations were located over the shallow part (<200 $\mathrm{m}$ depth) of the Goban Spur $\left(50^{\circ} \mathrm{N}, 10^{\circ} \mathrm{W}\right)$ (Fig. 1). Eight deeper stations (from 450 to $1400 \mathrm{~m}$ depth) were located over the continental slope at the Meriadzek Terrace $\left(48^{\circ} \mathrm{N}, 9^{\circ} \mathrm{W}\right)$ and the La Chapelle Bank (Table 1). Each campaign consisted of two legs allowing some stations to be revisited with a 1-2 week interval (Fig. 2). Revisited stations are denoted with a "b" following their numeral identifier. Due to shorter ship-time, sampling during the June 2006 campaign was limited to the area around the La Chapelle Bank, while during the two following campaigns sampling was carried in the whole area outlined above (Fig. 1 and Table 1). Near real-time MODIS Aqua remote sensing images were used to track phytoplankton community dynamics through phases of emergence and disintegration of coccolithophorid blooms during the campaigns (see also Suykens et al., 2010 for SeaWIFS images of ths study area). In order to put the campaign periods into context we generated time-series of [chl a], normalised water-leaving radiance at $555 \mathrm{~nm}$ (Lwn (555)), and photosynthetically active radiation (PAR) using data from NASA's Giovanni Ocean Color Radiometry 8-day Data Product Visualization portal (http://gdata1.sci.gsfc.nasa.gov/; accessed on January 6th 2011) (Fig. 3). Topographical information in Figs. 1 and 2 was obtained using ODV software (Schlitzer, R., Ocean Data View, http://odv.awi.de, 2011).

\subsection{Sample collection and analyses}

\subsubsection{Physical parameters}

Water samples were collected using a rosette of 12 Niskin bottles (10 l) coupled to a conductivity and temperature-pressure probe (CTD) (Seabird SBE21). Casts covered surface waters, pycnocline, and deeper waters down to at least $80 \mathrm{~m}$ depth. The reported values of sea surface temperature (SST) have been measured at $10 \mathrm{~m}$. The strength of the vertical density gradient $\left(\mathrm{N}^{2}\right)$ or stratification gradient, commonly referred to as the Brunt-Väisälä frequency, is defined as the oscillation frequency of a parcel of water following vertical displacement in a system initially at rest. To calculate $\mathrm{N}^{2}$ we used the adiabatic steric anomaly levelling method between $10 \mathrm{~m}$ and $100 \mathrm{~m}$ of depth (Millard et al., 1990). These depths were chosen to make sure that the upper value was within the mixed layer (where density was homogeneous), and that the bottom value was below the base of the pycnocline (Table 1). The upper mixed layer depth (MLD) was operationally defined as the depth where $\left(\sigma_{t}\right)$ increased by $\geqslant 0.1 \mathrm{~kg} \mathrm{~m}^{-3}$ compared to $\sigma_{t}$ at $10 \mathrm{~m}$ of depth. 


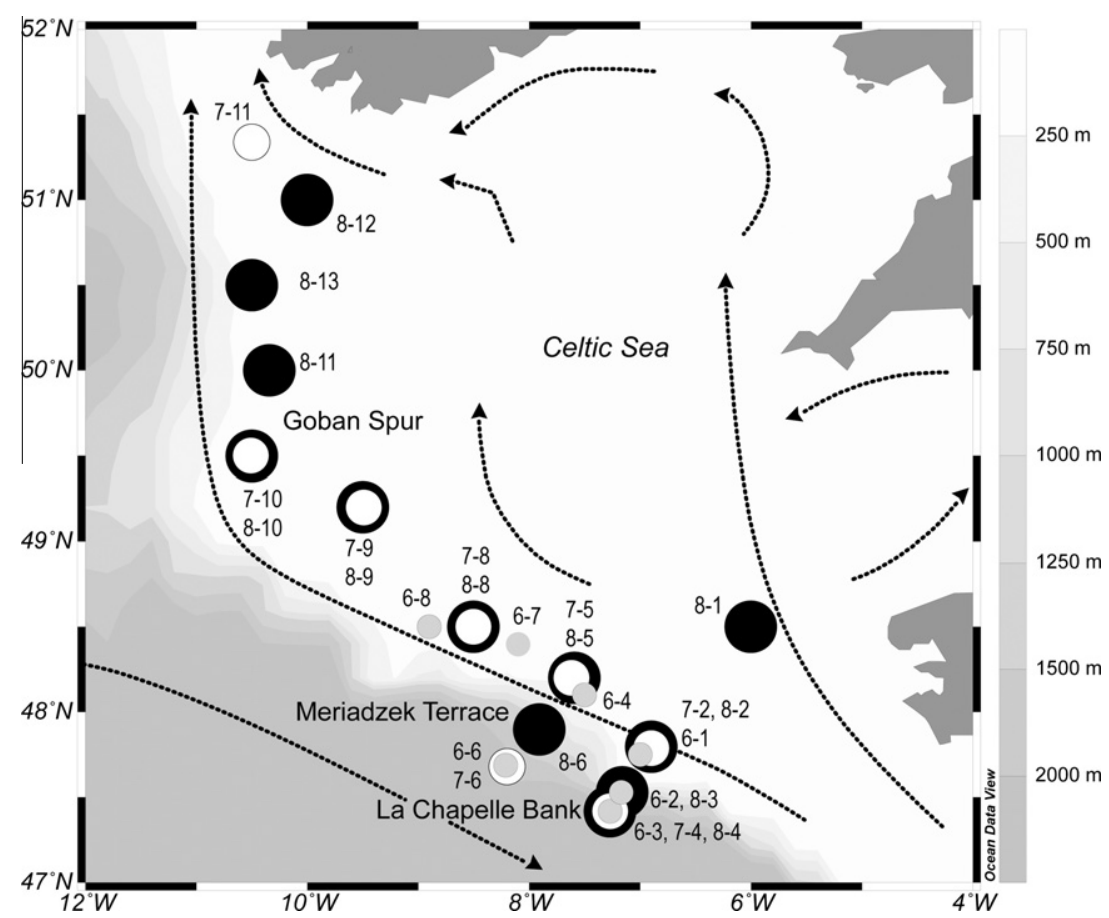

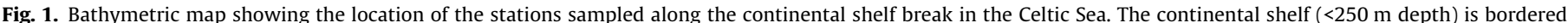

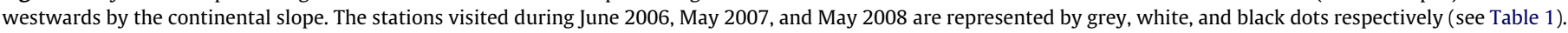
Dotted lines represent the main residual surface circulation (adapted from Suykens et al. (2010)).

Table 1

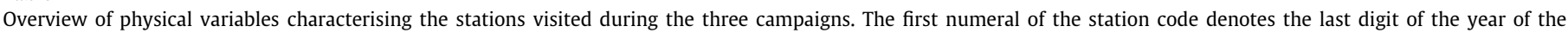

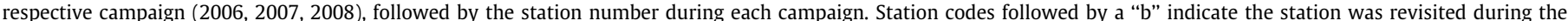

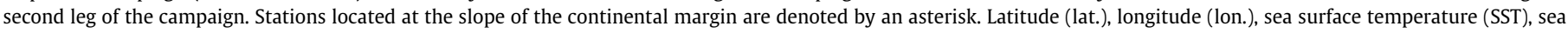
surface salinity (SSS), stratification degree (strat. deg.), mixed layer depth (MLD).

\begin{tabular}{|c|c|c|c|c|c|c|c|c|c|}
\hline Date & Station & Area & Lat. $\left({ }^{\circ} \mathrm{N}\right)$ & Lon. $\left({ }^{\circ} \mathrm{W}\right)$ & Bottom depth (m) & $\operatorname{SST}\left({ }^{\circ} \mathrm{C}\right)$ & SSS (psu) & Strat. deg. $\left(10^{-5} \mathrm{~s}^{-2}\right)$ & $\operatorname{MLD}(\mathrm{m})$ \\
\hline $31 / 05 / 2006$ & $6-1$ & La Chapelle & 47.75 & 7.00 & 157 & 13.03 & 35.61 & 3.34 & 32 \\
\hline $01 / 06 / 2006$ & $6-2^{*}$ & La Chapelle & 47.53 & 7.17 & 558 & 12.99 & 35.63 & 2.20 & 40 \\
\hline $01 / 06 / 2006$ & $6-3^{*}$ & La Chapelle & 47.42 & 7.27 & 1400 & 13.95 & 35.67 & 4.45 & 21 \\
\hline $02 / 06 / 2006$ & $6-4$ & Meriadzek & 48.10 & 7.50 & 163 & 13.28 & 35.60 & 2.31 & 34 \\
\hline $06 / 06 / 2006$ & $6-8$ & Meriadzek & 48.50 & 8.90 & 178 & 14.47 & 35.54 & 7.75 & 19 \\
\hline $07 / 06 / 2006$ & $6-6^{*}$ & Meriadzek & 47.69 & 8.21 & 1100 & 14.85 & 35.65 & 6.34 & 16 \\
\hline $07 / 06 / 2006$ & $6-7$ & Meriadzek & 48.40 & 8.10 & 164 & 14.51 & 35.57 & 7.29 & 20 \\
\hline $08 / 06 / 2006$ & $6-4 b$ & Meriadzek & 48.10 & 7.50 & 159 & 14.32 & 35.61 & 6.55 & 23 \\
\hline $09 / 06 / 2006$ & $6-1 b$ & La Chapelle & 47.75 & 7.00 & 158 & 14.32 & 35.62 & 6.00 & 22 \\
\hline $10 / 05 / 2007$ & $7-2$ & La Chapelle & 47.79 & 6.90 & 165 & 13.41 & 35.57 & 3.97 & 42 \\
\hline $12 / 05 / 2007$ & $7-5$ & Meriadzek & 48.20 & 7.62 & 172 & 12.97 & 35.53 & 3.57 & 39 \\
\hline $13 / 05 / 2007$ & $7-8$ & Meriadzek & 48.50 & 8.50 & 158 & 13.21 & 35.56 & 3.95 & 39 \\
\hline $14 / 05 / 2007$ & $7-9$ & Goban Spur & 49.20 & 9.49 & 154 & 12.98 & 35.49 & 4.53 & 43 \\
\hline $15 / 05 / 2007$ & $7-10$ & Goban Spur & 49.50 & 10.51 & 139 & 12.73 & 35.45 & 4.50 & 36 \\
\hline $16 / 05 / 2007$ & $7-11$ & Goban Spur & 51.34 & 10.50 & 150 & 12.30 & 35.31 & 5.23 & 39 \\
\hline $21 / 05 / 2007$ & $7-8 b$ & Meriadzek & 48.50 & 8.50 & 158 & 13.27 & 35.52 & 4.14 & 43 \\
\hline $22 / 05 / 2007$ & $7-5 b$ & Meriadzek & 48.22 & 7.59 & 172 & 13.30 & 35.52 & 4.40 & 36 \\
\hline $23 / 05 / 2007$ & $7-4^{*}$ & La Chapelle & 47.42 & 7.27 & 1200 & 13.38 & 35.63 & 2.28 & 54 \\
\hline $23 / 05 / 2007$ & $7-7^{*}$ & Meriadzek & 47.68 & 8.20 & 1100 & 13.49 & 35.59 & 3.59 & 36 \\
\hline $24 / 05 / 2007$ & $7-2 b$ & La Chapelle & 47.80 & 6.89 & 165 & 13.40 & 35.56 & 3.40 & 28 \\
\hline $07 / 05 / 2008$ & $8-1$ & Armorican & 48.50 & 6.00 & 122 & 12.42 & 35.39 & 3.21 & 13 \\
\hline $07 / 05 / 2008$ & $8-3^{*}$ & La Chapelle & 47.53 & 7.16 & 567 & 12.72 & 35.60 & 1.77 & 40 \\
\hline $08 / 05 / 2008$ & $8-2$ & La Chapelle & 47.80 & 6.90 & 167 & 12.75 & 35.48 & 2.71 & 15 \\
\hline $09 / 05 / 2008$ & $8-6^{*}$ & Meriadzek & 47.90 & 7.91 & 479 & 12.25 & 35.59 & 0.44 & 100 \\
\hline $10 / 05 / 2008$ & $8-5$ & Meriadzek & 48.20 & 7.59 & 174 & 12.91 & 35.51 & 2.91 & 25 \\
\hline $11 / 05 / 2008$ & $8-8$ & Meriadzek & 48.50 & 8.50 & 150 & 12.95 & 35.50 & 3.28 & 18 \\
\hline $12 / 05 / 2008$ & $8-9$ & Goban Spur & 49.20 & 9.50 & 154 & 12.91 & 35.47 & 4.05 & 15 \\
\hline $13 / 05 / 2008$ & $8-10$ & Goban Spur & 49.50 & 10.50 & 138 & 13.13 & 35.54 & 4.60 & 22 \\
\hline $14 / 05 / 2008$ & $8-11$ & Goban Spur & 50.50 & 10.50 & 159 & 12.70 & 35.58 & 3.25 & 14 \\
\hline $19 / 05 / 2008$ & $8-12$ & Goban Spur & 51.00 & 10.00 & 121 & 13.61 & 35.54 & 6.36 & 19 \\
\hline $20 / 05 / 2008$ & $8-13$ & Goban Spur & 50.00 & 10.34 & 129 & 13.42 & 35.58 & 4.91 & 34 \\
\hline $21 / 05 / 2008$ & $8-9 b$ & Goban Spur & 49.20 & 9.50 & 154 & 13.62 & 35.52 & 5.13 & 23 \\
\hline $22 / 05 / 2008$ & $8-5 b$ & Meriadzek & 48.20 & 7.60 & 174 & 13.53 & 35.56 & 3.89 & 39 \\
\hline $23 / 05 / 2008$ & $8-4^{*}$ & La Chapelle & 47.42 & 7.27 & 1200 & 14.30 & 35.61 & 5.13 & 20 \\
\hline
\end{tabular}



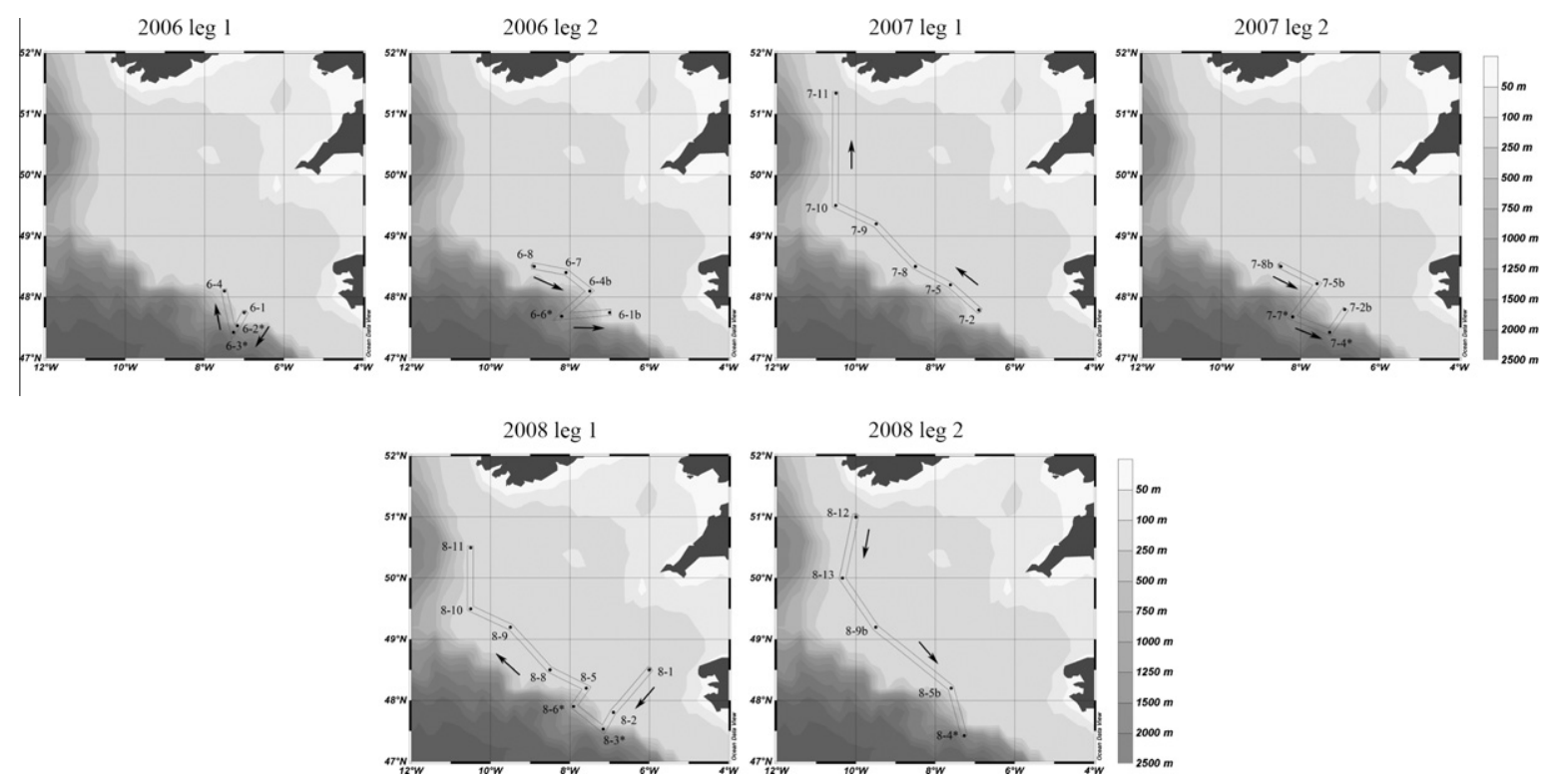

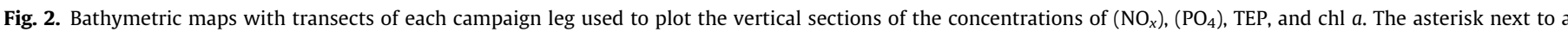
station's number indicates it is situated on the slope of the continental margin.

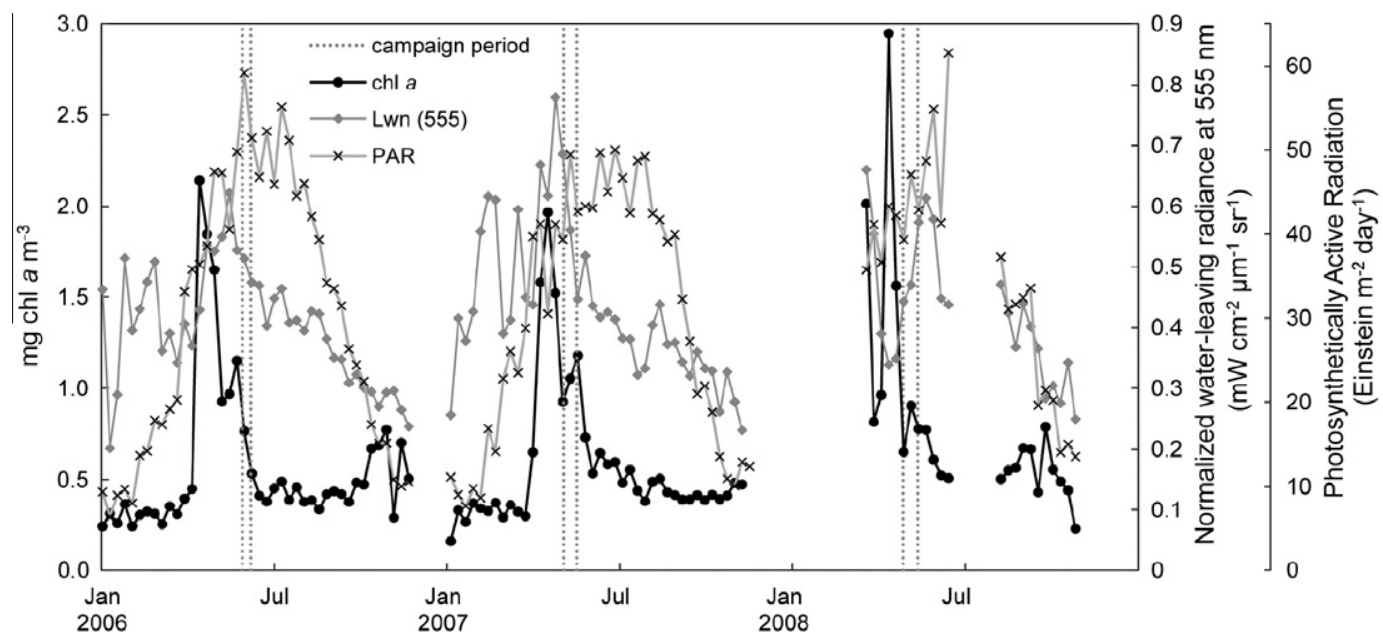

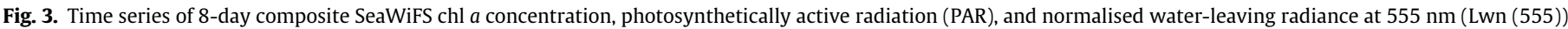

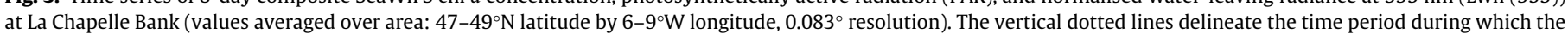
campaigns took place. Note that Lwn (555) from January to March can be biased due to cloud coverage (Steve Groom, personal communication).

Nutrient concentration data (collected every $10 \mathrm{~m}$, see below) were used to compute the depth of the nitracline, a proxy of nutrient supply to the upper mixed layer of the ocean, which was operationally defined as the shallowest depth at which nitrate + nitrite concentration $\left(\mathrm{NO}_{x}\right)$ exceeded $1.00 \mu \mathrm{moll}^{-1}$ (Cermeño et al., 2008; Landry et al., 2009).

\subsubsection{Dissolved nutrients}

Samples for the measurement of dissolved phosphate $\left(\mathrm{PO}_{4}\right)$, nitrate and nitrite $\left(\mathrm{NO}_{x}\right)$ - further referred to as nitrate-, and dissolved silicate $(\mathrm{dSi})$ were gently filtered through $0.4 \mu \mathrm{m}$ pore size Nuclepore filters $(\varnothing=47 \mathrm{~mm})$. $\mathrm{PO}_{4}$ and $\mathrm{dSi}$ samples were stored at $4{ }^{\circ} \mathrm{C}$ until onboard analysis by spectrophotometry, using the molybdate/ascorbic acid method (Grasshoff et al., 1983); $\mathrm{NO}_{x}$ samples were stored at $-20^{\circ} \mathrm{C}$ until analysis and their concentration was determined spectrophotometrically using a Skalar Autoanalyzer system (Grasshoff et al., 1983). The detection limit was $0.01 \mu \mathrm{mol} \mathrm{l}^{-1}$ for $\mathrm{PO}_{4}$ and $0.05 \mu \mathrm{mol} \mathrm{l}^{-1}$ for $\mathrm{NO}_{x}$ and $\mathrm{dSi}$.

\subsubsection{Particulate matter}

Particulate organic and inorganic carbon samples (POC and PIC) were collected by low-vacuum filtration of $0.2-2.01$ seawater through pre-combusted $\left(4 \mathrm{~h}\right.$ at $\left.500{ }^{\circ} \mathrm{C}\right) \mathrm{GF} / \mathrm{F}$ filters. The filter samples were stored at $-20^{\circ} \mathrm{C}$ until analysis (within 3 months after the cruise) and dried overnight at $50{ }^{\circ} \mathrm{C}$ prior to analysis. POC was determined using a Fisons NA-1500 elemental analyzer after carbonate removal from the filters by overnight $\mathrm{HCl}$ fuming. Total particulate carbon (TPC) content was determined using unacidified filters. PIC content was derived from the difference between total particulate carbon content and POC content. Four to five standards of certified reference stream sediment (STSD-2) from the Geological Survey of Canada, together with three to four blank filters, were used for calibration. Particulate nitrogen (PN) was determined from unacidified filters in the same way as TPC. The minimum detection limits for $\mathrm{C}$ and $\mathrm{N}$ were $0.17 \mu \mathrm{mol} \mathrm{Cl^{-1 }}$ and $0.36 \mu \mathrm{mol} \mathrm{N}{ }^{-1}$.

Transparent exopolymer particles (TEP) were measured spectrophotometrically after alcian blue staining and hydrolysis 
(Passow and Alldredge, 1995). TEP concentration determined this way reflects the density of stainable moieties in particulate matter, such as acidic and sulphated sugars, and should thus be considered as a semi-quantitative measure of TEP concentration expressed in micrograms xanthan gum equivalents per litre ( $\mu \mathrm{g} \mathrm{X} \mathrm{eq.} \mathrm{l}^{-1}$ ).

\subsubsection{Microscopic phytoplankton identification}

Microscopic qualitative screening of phytoplankton diversity in water samples $(100 \mathrm{ml})$ from the upper mixed layer of stations from each campaign was performed by the Utermöhl sedimentation method (Utermöhl, 1958) using a Zeiss inverted microscope. These samples were preserved using a mixture of alkaline Lugol's iodine solution $(0.1 \% \mathrm{v} / \mathrm{v})$ and borate-buffered formaldehyde solution $(0.9 \% \mathrm{v} / \mathrm{v}$, all final concentrations) (Sherr and Sherr, 1993). The qualitative microscopic screening was performed to verify the presence of the dominant phytoplankton groups in conjunction with specific pigment biomarkers (Havskum et al., 2004; Irigoien et al., 2004). Sea surface water samples (1.0 l) for scanning electron microscopy (SEM) were filtered through polycarbonate membrane filters $(0.8 \mu \mathrm{m}$ pore size, $\varnothing 47 \mathrm{~mm}$, Millipore), dried onboard for $12 \mathrm{~h}$ at $50^{\circ} \mathrm{C}$ and stored dry before being mounted onto microscope slides and coated with gold (Bollmann et al., 2002). Coccolithophores were identified by scanning electron microscopy (SEM) using a Jeol JSM 5600 LV at a minimum magnification of 600 times. Taxonomic identification was performed according to Hasle and Syvertsen (1997), Heimdal (1997), Steidinger and Tangen (1997), and Throndsen (1997).

\subsubsection{Microalgal pigments and chlorophyll a partitioning}

For pigment analysis, $0.5-3.51$ of seawater was filtered through glass fibre filters (Whatman $\mathrm{GF} / \mathrm{F}, \varnothing 47 \mathrm{~mm}$ ) using a low vacuum pressure ( $<200 \mathrm{mbar}$ ). The filters were stored in liquid nitrogen until analysis. Extraction of the pigments was performed in a $90 \%$ acetone aqueous solution, spiked with an internal standard (trans- $\beta$-apo- $8^{\prime}$-carotenal), while cell disruption was further facilitated by sonification for $30 \mathrm{~s}$ with $50 \mathrm{~W}$ pulses (Bidigare et al., 2005). The extracts were cleared from debris by filtration through a $0.2 \mu \mathrm{m}$ Teflon syringe filter after centrifugation for $4 \mathrm{~min}$ at $700 \mathrm{~g}$ (at $-5{ }^{\circ} \mathrm{C}$ ). Pigment extracts were analysed by high pressure liquid chromatography (HPLC) according to the method of Wright et al. (Wright et al., 1991; Wright and Jeffrey, 1997) using an Agilent 1100 series HPLC system equipped with an Machery-Nagel reverse-phase $C_{18}$ column (Nucleodur $C_{18}$ pyramid, pore size $100 \AA$, particle size $5 \mu \mathrm{m}$ ). Deionised water (Milli-Q) was added to extracts to avoid peak distortion of early eluting peaks (Zapata and Garrido, 1991), preventing the loss of non-polar pigments prior to injection. Pigments were identified by comparison of retention times and absorption spectra and quantified by calculating response factors using pure pigment standards (supplied by DHI Lab, Denmark). We measured the concentration of the following pigments: chlorophyll $c_{3}$, chlorophyll $c_{1}+c_{2}$, peridinin, 19'-butanoyloxyfucoxanthin, fucoxanthin, 19'-hexanoyloxyfucoxanthin, pasinoxanthin, violaxanthin, diadinoxanthin, alloxanthin, zeaxanthin, chlorophyll $b$, and chlorophyll $a$. Pigment names are abbreviated according to the recommendations by the Scientific Committee on Oceanographic Research Working Group 78 (Jeffrey and Mantoura, 1997) (Table 2).

Quantification of the dominant phytoplankton groups was performed by means of a CHEMTAX (V1.95) routine using multiple runs $(n=64)$ and depth bins $(n=6)$ per year (Mackey et al., 1996; Latasa, 2007). Chlorophyll $a$ was partitioned between the main phytoplankton groups identified by microscopic qualitative screening of samples from the depth of chl $a$ maximum and based on pigment biomarker ratios from relevant literature (Johnsen and Sakshaug, 1993; Mackey et al., 1996; Liu et al., 1999; Llewellyn and Gibb, 2000; Schlüter et al., 2000; Gibb et al., 2001; Latasa et al.,
2004; Six et al., 2004; Zapata et al., 2004) (Tables 2, SP1, SP2 and SP3). Since coccolithophores, and E. huxleyi in particular, were the dominant prymnesiophyte in our study we used literaturebased pigment biomarker ratios of E. huxleyi for this group. The pigment butanoyloxyfucoxanthin was attributed to the chrysophyte group s.l., i.e. chrysophytes and pelagophytes (Andersen et al., 1996; Rodriguez et al., 2003). Because Rhizosolenia spp. were part of the diatom community, part of [ $\mathrm{chl} c_{3}$ ] was attributed to the diatom group (Richardson et al., 1996). Having low taxonomic specificity, diadinoxanthin was omitted from the CHEMTAX analysis (Gibb et al., 2001).

Initial pigment ratios used for each phytoplankton group (Table SP1) were multiplied by a random value between 0.65 and 1.35 for each CHEMTAX run to overcome the sensitivity of the routine to initial seed values. We used the mean of the five best results from the 64 runs, having the lowest residual square means, as an estimate of phytoplankton group abundances. Table SP2 shows the average pigment ratios of the best results after performing the CHEMTAX routine for the May 2008 campaign using the $20 \mathrm{~m}$ depth bin. Finally, areal values of chl $a$ concentration were calculated by trapezoidal integration of volumetric concentrations from 0 to $80 \mathrm{~m}$ depth.

\subsection{Statistical treatment of data}

Averages are reported as their arithmetic mean followed by their standard deviation. We used Spearman rank correlations to assess the degree and significance of linear relationships between two variables. To test for the difference of areal chl a concentrations between campaign years a non-parametric permutational analysis of variance (PERMANOVA) was performed using the PRIMER v6 and PERMANOVA + add-on software (PRIMER-E Ltd., Plymouth, UK) (Clarke and Gorley, 2006; Anderson et al., 2008). To test for the difference in values of environmental variables between campaign years and the shelf versus slope position of stations we performed PERMANOVA's with a fully crossed two-factor design using type III (partial) sums of squares. The interaction term informs about the difference in environmental variables among campaign years. In case of significant 'shelf-slope $\times$ year' interactions, pair-wise tests of 'year' within 'shelf-slope' were performed to investigate the difference between years at shelf or slope location. Because of the restricted number of possible permutations in 'shelf-slope' effect and pair-wise tests, $p$-values were obtained from Monte Carlo samplings (Anderson and Robinson, 2003). A Euclidean distance-based resemblance matrix was used and probability values were obtained by permutation $\left(n=10^{4}\right)$. Nutrient concentrations were log transformed to approach normal distribution.

Unconstrained multivariate analyses of phytoplankton group biomass were performed using principal coordinates analysis (PCO) to investigate differences between stations and years in terms of phytoplankton community structure and its relation to environmental variables. Only phytoplankton samples from the upper mixed layer and including the depth of the chl $a$ maximum were used (except at station 8-6 where only samples above and including the depth of the chl $a$ maximum were used because its water column was mixed much deeper than the euphotic depth). Phytoplankton group biomasses were square root transformed to reduce the contribution of highly abundant groups in relation to less abundant ones in the calculation of the Bray-Curtis measure. The significance of the relation between environmental variables (plotted as supplementary variables) and the PCO axes of the phytoplankton community were tested using Spearman rank correlations (PRIMER-E Ltd., Plymouth, UK). We adopted a probability threshold of $p<0.05$ for all analyses, unless stated otherwise. 
Table 2

Chemotaxonomic relationships used in this study. Species in bold emphasise the value of the associated pigment as a major taxonomic biomarker.

\begin{tabular}{|c|c|c|}
\hline pigment & abbreviation & $\begin{array}{l}\text { occurrence in } \\
\text { phytoplankton groups }\end{array}$ \\
\hline alloxanthin & allo & cryptophytes \\
\hline 19'-butanoyloxyfucoxanthin & but-fuco & chrysophytes s.l. \\
\hline chlorophyll $a$ & chl $a$ & $\begin{array}{l}\text { total algal biomass } \\
\text { (including Synechococcus) }\end{array}$ \\
\hline chrolophyll $b$ & $\operatorname{chl} b$ & prasinophytes \\
\hline chlorophyll $c_{3}$ & $\operatorname{chl} c_{3}$ & $\begin{array}{l}\text { prymnesiophytes, } \\
\text { chrysophytes s.l., diatoms }\end{array}$ \\
\hline fucoxanthin & fuco & $\begin{array}{l}\text { diatoms, prymnesiophytes, } \\
\text { chrysophytes s.l. }\end{array}$ \\
\hline 19'-hexanoyloxyfucoxanthin & hex-fuco & $\begin{array}{l}\text { prymnesiophytes } \\
\text { (coccolithophores) }\end{array}$ \\
\hline peridinin & perid & dinoflagellates \\
\hline violaxanthin & viola & prasinophytes \\
\hline prasinoxanthin & pras & prasinophytes \\
\hline zeaxanthin & zea & $\begin{array}{l}\text { Synechococcus, } \\
\text { prasinophytes }\end{array}$ \\
\hline
\end{tabular}

\section{Results}

\subsection{General setting, thermal stratification and nutrient levels}

The stations were located along the shelf break and on the shelf of the Celtic Sea in the La Chapelle Bank (LC), the Meriadzek Terrace (M) and the Goban Spur (GS) areas (Figs. 1 and 2, Table 1). Each campaign (2006, 2007, and 2008) took place after the main diatom spring bloom which took place in April (Fig. 3).

Sea surface temperature (SST) was on average higher in June $2006\left(13.84 \pm 0.76^{\circ} \mathrm{C}\right)$ than in May $2007\left(13.25 \pm 0.16^{\circ} \mathrm{C}\right)$ and May $2008\left(13.04 \pm 0.66^{\circ} \mathrm{C}\right.$ ) (Table SP4 and pairwise tests: $p_{2007}=0.042$ and $p_{2008}=0.023$ ). Overall, SST did not significantly differ between shelf and slope stations (Tables 1 and SP4). The water column at most slope stations, except 6-6 and 8-4, lacked a distinct pycnocline (or thermocline) and was significantly less stratified than at the shelf stations (slope LC\&M: $3.28 \pm 1.95 \times$
$10^{-5} \mathrm{~s}^{-2}$; shelf LC\&M: $4.34 \pm 1.65 \times 10^{-5} \mathrm{~s}^{-2}$; GS: $4.73 \pm 0.85 \times$ $10^{-5} \mathrm{~s}^{-2}$ ) (Tables 1,3 , SP4 and SP5). In general, there was a sharpening of the thermocline at stations revisited during the second leg (e.g. 6-1 and 6-4) (Table SP5). Stratification degree of the water column displayed a low but statistically significant negative relationship with bottom depth (reflecting the slope versus shelf divide) (Table 4). Differences in MLD were significant between shelf and slope stations yet inter-annual differences were not significant (Tables 1, 3 and SP4) (LC\&M: 2006: $25 \pm 8 \mathrm{~m}$; 2007: $40 \pm 6 \mathrm{~m}$; 2008: $30 \pm 22 \mathrm{~m}$ ).

Nutrients in the upper mixed layer of the shelf stations were usually depleted during the three campaigns, as indicated by the low maximum values measured in the upper mixed layer $\left(\mathrm{NO}_{x}<1.47 \mu \mathrm{mol} \mathrm{l}^{-1} ; \quad \mathrm{PO}_{4}<0.10 \mu \mathrm{mol} \mathrm{l}^{-1} ; \quad \mathrm{dSi}<1.95 \mu \mathrm{mol} \mathrm{l}^{-1}\right)$ (Figs. 4-6 and Table 3). In contrast, most slope stations had higher nitrate and phosphate levels (maximum values for slope stations: $\left.\mathrm{NO}_{x}<2.45 \mu \mathrm{mol} \mathrm{l}^{-1} ; \quad \mathrm{PO}_{4}<0.26 \mu \mathrm{mol} \mathrm{l}^{-1} ; \quad \mathrm{dSi}<1.40 \mu \mathrm{mol} \mathrm{l}^{-1}\right)$ (Figs. 4 and 5 and Table SP4), except station 8-4 which had depleted levels. Neither N:P, nor dSi:N ratios were significantly higher on the slope than on the shelf (Table SP4). The depth profiles of $\mathrm{PO}_{4}, \mathrm{NO}_{x}$, and $\mathrm{dSi}$ concentration were inversely related to the temperature profiles (Pearson $r=-0.69,-0.68$ and -0.51 , each significant at $p<0.01$ ). As a consequence of variable vertical mixing, the depth of the nitracline was very variable (Table 3 ) and estimated to be between surface and $38 \mathrm{~m}$ in 2006, between surface and $43 \mathrm{~m}$ in 2007, and between surface and $48 \mathrm{~m}$ in 2008. Nitracline depth was negatively correlated to bottom depth (Table 4). Finally, stations visited in 2007 were much more homogeneous in terms of nutrient levels and stratification degree than those visited in 2006 and 2008 (Figs. 4-6 and Table 1).

\subsection{Particulate matter distribution}

Particulate organic carbon (POC) and particulate nitrogen (PN) showed higher concentrations above the pycnocline than at $80 \mathrm{~m}$ depth (Table SP5). POC concentrations in the upper $80 \mathrm{~m}$ of the water column varied from 1.1 to $14.7 \mu \mathrm{mol}^{-1}$ in 2006 , from 1.8 to $19.1 \mu \mathrm{mol}^{-1}$ in 2007, and from 0.7 to $15.8 \mu \mathrm{mol}^{-1}$ in 2008 . PN concentrations varied from 0.2 to $1.9 \mu \mathrm{mol}^{-1}$ in 2006 , from

Table 3

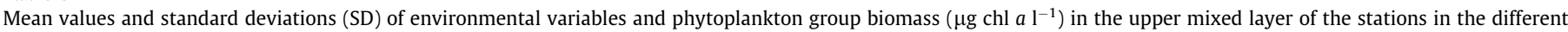

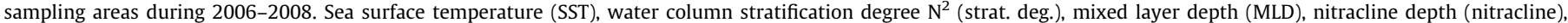

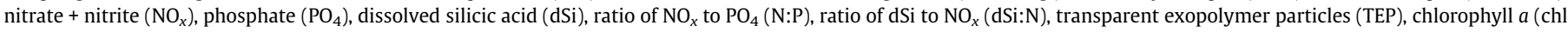
a).

\begin{tabular}{|c|c|c|c|c|c|c|c|c|c|c|c|c|c|c|c|c|}
\hline & \multirow{2}{*}{\multicolumn{4}{|c|}{$\begin{array}{l}\text { June } 2006 \\
\text { La Chapelle and Meriadzek } \\
\end{array}$}} & \multicolumn{6}{|c|}{ May 2007} & \multicolumn{6}{|c|}{ May 2008} \\
\hline & & & & & \multicolumn{4}{|c|}{ La Chapelle and Meriadzek } & \multirow{2}{*}{\multicolumn{2}{|c|}{$\begin{array}{l}\text { Goban Spur } \\
\text { Shelf }\end{array}$}} & \multicolumn{4}{|c|}{ La Chapelle and Meriadzek } & \multirow{2}{*}{\multicolumn{2}{|c|}{$\begin{array}{l}\text { Goban Spur } \\
\text { Shelf }\end{array}$}} \\
\hline & \multicolumn{2}{|l|}{ Slope } & \multicolumn{2}{|l|}{ Shelf } & \multicolumn{2}{|l|}{ Slope } & \multicolumn{2}{|l|}{ Shelf } & & & \multicolumn{2}{|l|}{ Slope } & \multicolumn{2}{|l|}{ Shelf } & & \\
\hline & Mean & SD & Mean & $\mathrm{SD}$ & mean & SD & Mean & SD & Mean & $\mathrm{SD}$ & Mean & SD & Mean & SD & Mean & SD \\
\hline SST $\left({ }^{\circ} \mathrm{C}\right)$ & 13.85 & 1.07 & 13.94 & 0.68 & 13.34 & 0.07 & 13.22 & 0.16 & 12.65 & 0.34 & 13.03 & 1.07 & 13.04 & 0.33 & 13.26 & 0.36 \\
\hline strat. deg. $\left(10^{-5} \mathrm{~s}^{-2}\right)$ & 4.33 & 2.07 & 5.54 & 2.21 & 2.94 & 0.93 & 3.91 & 0.37 & 4.75 & 0.41 & 2.45 & 2.42 & 3.20 & 0.52 & 4.72 & 1.05 \\
\hline $\operatorname{MLD}(\mathrm{m})$ & 26 & 13 & 25 & 7 & 45 & 13 & 38 & 5 & 39 & 3 & 53 & 42 & 24 & 11 & 21 & 7 \\
\hline ntracline (m) & 4 & 6 & 30 & 5 & 13 & 19 & 18 & 16 & 26 & 23 & 9 & 16 & 24 & 7 & 33 & 13 \\
\hline $\mathrm{NO}_{x}\left(\mu \mathrm{mol} \mathrm{l}^{-1}\right)$ & 1.53 & 0.86 & 0.26 & 0.27 & 1.35 & 1.19 & 0.87 & 0.41 & 0.79 & 0.37 & 2.32 & 2.00 & 0.58 & 0.74 & 0.22 & 0.04 \\
\hline $\mathrm{PO}_{4}\left(\mu \mathrm{mol} \mathrm{l}^{-1}\right)$ & 0.12 & 0.06 & 0.04 & 0.07 & 0.12 & 0.04 & 0.08 & 0.02 & 0.07 & 0.01 & 0.20 & 0.12 & 0.08 & 0.04 & 0.03 & 0.01 \\
\hline $\mathrm{dSi}\left(\mu \mathrm{mol} \mathrm{l}^{-1}\right)$ & 1.01 & 0.61 & 0.73 & 0.51 & 0.69 & 0.72 & 0.63 & 0.76 & 0.48 & 0.29 & 0.80 & 0.67 & 0.46 & 0.33 & 0.12 & 0.09 \\
\hline $\mathrm{N}: \mathrm{P}$ & 12.36 & 1.84 & 6.05 & 5.12 & 10.10 & 6.77 & 12.09 & 7.39 & 11.42 & 4.35 & 9.69 & 5.40 & 5.48 & 4.42 & 10.42 & 10.16 \\
\hline dSi:N & 0.70 & 0.21 & 6.36 & 5.39 & 0.45 & 0.14 & 0.57 & 0.47 & 0.81 & 0.70 & 0.30 & 0.13 & 1.70 & 2.22 & 0.56 & 0.41 \\
\hline TEP ( $\mu$ g X eq. $\left.\mathrm{I}^{-1}\right)$ & 1101 & 597 & 520 & 538 & 138 & 158 & 23 & 15 & 22 & 11 & 38 & 33 & 49 & 21 & 67 & 26 \\
\hline chl $a\left(\mu \mathrm{g} \mathrm{l}^{-1}\right)$ & 1.44 & 0.46 & 0.90 & 0.34 & 0.59 & 0.00 & 0.46 & 0.10 & 0.57 & 0.37 & 0.39 & 0.14 & 0.68 & 0.60 & 0.68 & 0.41 \\
\hline diatom & 0.11 & 0.12 & 0.39 & 0.25 & 0.05 & 0.06 & 0.22 & 0.13 & 0.05 & 0.07 & 0.12 & 0.03 & 0.08 & 0.08 & 0.13 & 0.14 \\
\hline dinoflagellate & 0.15 & 0.07 & 0.04 & 0.03 & 0.03 & 0.01 & 0.04 & 0.04 & 0.03 & 0.02 & 0.04 & 0.01 & 0.08 & 0.04 & 0.07 & 0.08 \\
\hline prymnesiophyte & 0.86 & 0.34 & 0.17 & 0.17 & 0.24 & 0.12 & 0.07 & 0.11 & 0.20 & 0.08 & 0.13 & 0.11 & 0.25 & 0.31 & 0.27 & 0.29 \\
\hline chrysophyte & 0.10 & 0.02 & 0.07 & 0.03 & 0.07 & 0.05 & 0.02 & 0.01 & 0.03 & 0.03 & 0.02 & 0.00 & 0.05 & 0.04 & 0.06 & 0.05 \\
\hline prasinophyte & 0.14 & 0.09 & 0.15 & 0.07 & 0.05 & 0.02 & 0.03 & 0.05 & 0.15 & 0.08 & 0.02 & 0.01 & 0.09 & 0.09 & 0.05 & 0.05 \\
\hline cryptophyte & 0.03 & 0.02 & 0.10 & 0.08 & 0.09 & 0.11 & 0.05 & 0.08 & 0.07 & 0.09 & 0.04 & 0.02 & 0.13 & 0.08 & 0.08 & 0.06 \\
\hline Synechococcus & 0.03 & 0.01 & 0.01 & 0.00 & 0.07 & 0.01 & 0.03 & 0.03 & 0.04 & 0.03 & 0.01 & 0.01 & 0.01 & 0.00 & 0.01 & 0.00 \\
\hline
\end{tabular}


0.1 to $3.8 \mu \mathrm{mol} \mathrm{l}^{-1}$ in 2007, and from 0.2 to $3.4 \mu \mathrm{mol}^{-1}$ in 2008 . $\mathrm{POC}$ and PN were significantly correlated during each campaign (2006: $r=0.87, n=33 ; 2007: r=0.75, n=38 ; 2008: r=0.91$, $n=58$ ), with the median C:N molar ratio in the upper $80 \mathrm{~m}$ of the water column above the Redfield ratio $(\mathrm{C}: \mathrm{N}=6.6)$ in 2006 (7.74) and 2007 (7.17) implying particulate organic matter was enriched in carbon (cf. Harlay et al., 2009), and below the Redfield ratio in 2008 (4.92).

In contrast to POC, PIC concentrations were not always higher at surface. PIC concentrations varied from 0.3 to $10.6 \mu \mathrm{mol} \mathrm{l}^{-1}$ in 2006, from 0.2 to $16.1 \mu \mathrm{mol}^{-1}$ in 2007 , and from undetectable to $12.4 \mu \mathrm{mol} \mathrm{l}^{-1}$ in 2008 (Table SP5). PIC and POC were not correlated to each other within campaigns, and the median PIC:POC molar ratios in the upper $80 \mathrm{~m}$ of the water column were similar between campaigns (2006: 0.44; 2007: 0.36; 2008: 0.30).

TEP concentration generally decreased with increasing depth (upper mixed layer: $231 \pm 425 \mu \mathrm{g} \mathrm{X} \mathrm{eq.} \mathrm{l}^{-1} ; 80 \mathrm{~m}$ : $52 \pm 62 \mu \mathrm{g} \mathrm{X}$ eq. $1^{-1}$ ) (Fig. 7) (see also Harlay et al., 2009). Maximum TEP concentrations at each station ranged from 414 (station 6-1) to $3199 \mu \mathrm{g} \mathrm{X} \mathrm{eq.} \mathrm{I}^{-1}$ (station 6-2) during the June 2006 campaign, from 14 (station 7-2) to $269 \mu \mathrm{g} \mathrm{X} \mathrm{eq.} \mathrm{l}^{-1}$ (station 7-7) in 2007, and from 19 (station 8-1) to $132 \mu \mathrm{g} \mathrm{X} \mathrm{eq.} \mathrm{l}^{-1}$ (station 8-9) in 2008. TEP concentrations were higher at the LC and M shelf stations during 2006 than during 2007 and 2008 (Table 3).

\subsection{Phytoplankton community composition and standing stocks}

Depth of chl a maxima occurred around the nitracline or at surface in stations having a deeper mixed layer (Fig. 8 and Table SP5). The maximum level of chl $a$ (Fig. 9) was always situated in the upper $40 \mathrm{~m}$ of the water column $\left(0.72 \pm 0.49 \mu \mathrm{g} \mathrm{l}^{-1}\right)$, with negligible chl $a$ levels measured at $80 \mathrm{~m}$ depth $\left(0.16 \pm 0.19 \mu \mathrm{g} \mathrm{l}^{-1}\right)$ (Fig. 8). Areal [chl a] showed significant inter-annual variation but no relationship with the location of the stations on the shelf or the slope of the continental margin (Table SP4 and Fig. 9). Average areal [chl $a$ ] per year were significantly higher in June 2006 $\left(63.8 \pm 26.5 \mathrm{mg} \mathrm{chl} a \mathrm{~m}^{-2}\right)$ than in May $2007(27.9 \pm 8.4 \mathrm{mg} \mathrm{chl}$ $\left.a \mathrm{~m}^{-2}\right)$ and May $2008\left(41.3 \pm 21.8 \mathrm{mg} \mathrm{chl} a \mathrm{~m}^{-2}\right)$ (pairwise tests: $p_{2007}=0.044$ and $\left.p_{2008}<0.001\right)$ (Table SP6). The range of maximal [chl $a$ ] and areal [chl $a$ ] per station was quite wide, especially in 2006 and 2008 (Fig. 9 and Table SP3).

During the study period, phytoplankton communities in the study area were mostly dominated by diatoms and/or prymnesiophytes, which could constitute up to $72 \%$ and $89 \%$ of total phytoplankton biomass (chl $a$ ), respectively (Table 5, Figs. SP1 and SP2). Prasinophytes, cryptophytes and dinoflagellates as co-dominants making up at least $20 \%$ of the phytoplankton biomass (chl $a$ ) on occasion (Fig. 9). Light microscopy observations showed that diatom communities in 2006 were mainly represented by the genera Rhizosolenia, Bacteriastrum, Thalassiosira, Thalassionema, Chaetoceros and Pseudo-nitzschia. Light microscopy observations showed that prymnesiophytes were mainly composed of coccolithophores. Observations by SEM confirmed that coccolithophores were mainly represented by the coccolithophore Emiliania huxleyi, but other taxa were observed as well (Syracosphaera spp. and Gephyrocapsa oceanica). The genera Protoperidinium, Dinophysis, Ceratium, Gymnodinium and Gyrodinium were common dinoflagellate representatives. Furthermore, molecular data confirmed that prasinophytes were represented by Micromonas pusilla (Van Oostende et al., unpublished-a). Chrysophytes and Synechoccocus never dominated the phytoplankton community during the study period.

\subsection{Phytoplankton community and environmental variables}

Principal coordinates analysis of the phytoplankton groups' biomass data (only upper mixed layer samples, including the depth of the chl $a$ maximum, $n=93$ ) captured $67 \%$ of the total variation in the phytoplankton community along the first two axes (Fig. 10). The first and second PCO axes represent a gradient from low to high biomass of all phytoplankton groups. Diatom biomass varied independently from the other phytoplankton groups (except for a significant negative correlation with Synechococcus, data not shown) along the second PCO axis. Samples from the 2006 campaign, and to a lesser degree those of the 2008 campaign, were characterised by higher chl $a$ values, while most 2007 samples had low biomass values and are located in the lower left part of the diagram (see also Figs. 8 and 9). Only TEP concentration was positively correlated to the variation in phytoplankton groups biomass (first two PCO axes) while nutrient concentrations $\left(\mathrm{NO}_{x}\right.$, $\mathrm{PO}_{4}, \mathrm{dSi}$ ) and the ratios of $\mathrm{dSi}: \mathrm{N}$ and $\mathrm{N}: \mathrm{P}$ were not (Fig. 10 and Table 6). Note that stratification degree of the water column, the depth of the nitracline, MLD and bottom depth (reflecting the slope versus shelf divide) were not correlated to these PCO axes, nor to any of the phytoplankton groups (except a slightly negative correlation between dinoflagellates and nitracline depth) (Fig. 11 and Table 6). TEP concentration, on the other hand, was positively correlated to [chl $a$ ] and the biomass of coccolithophores, chrysophytes, prasinophytes and dinoflagellates, and to the stratification degree of the water column, but not to diatom biomass (Fig. 11, Tables 4 and 6). Diatom biomass was negatively correlated to concentration of $\mathrm{NO}_{x}$ and the $\mathrm{N}: \mathrm{P}$ ratio (Table 6).

Finally, we assessed the relationship between the occurrence of specific phytoplankton groups and the ratios of environmental variables by focusing on phytoplankton communities with above median total [chl $a$ ] ( $\left.n=44,>0.66 \mu \mathrm{g} \mathrm{chl} a \mathrm{l}^{-1}\right)$ and using the biomass proportions of the phytoplankton groups in these communities. Prymnesiophytes tended to dominate the phytoplankton assemblage during conditions of high $\mathrm{N}: \mathrm{P}$ ratios and low dSi:N ratios, while diatoms showed a tendency to dominate the phytoplankton assemblage during inverse conditions (Table 7).

\section{Discussion}

We studied the dynamics of phytoplankton standing stocks and community structure during late spring coccolithophore blooms along the continental margin of the Celtic Sea over a period of 3 years (2006-2008). We related the spatial and temporal development of these blooms to a suite of physical, geochemical, and biological variables in order to identify the main environmental conditions driving the wax and wane of these blooms, and to discuss the potential importance of phytoplankton community composition on the carbon balance and export in this area.

\subsection{Environmental setting of the blooms and phytoplankton standing stocks during late spring}

Our data show that nutrients were largely depleted in the study area during late spring concentrations and that surface chl $a$ concentrations were typically lower than those reported during the main diatom spring bloom event, as extrapolated from SeaWiFS 8-day averages (Fig. 3) prior to the campaign (e.g. for the La Chapelle area: SeaWiFS 8-day averaged chl $a$ concentration 2006-2008 between 15 April and 1 May: $1.80 \pm 0.54 \mu \mathrm{g}$ chl $a \mathrm{l}^{-1}$ compared to campaign periods: $\left.0.89 \pm 0.17 \mu \mathrm{g} \mathrm{chl} a \mathrm{l}^{-1}\right)$. The observed range in surface chl $a\left(0.27-2.31 \mu \mathrm{g} \mathrm{chl} a \mathrm{l}^{-1}\right.$ at chl $a$ maximum) is within the ranges reported by other studies of the NE Atlantic (Gibb et al., 2001; Leblanc et al., 2009; Painter et al., 2010a) or the Bay of Biscay and the Celtic Sea during a similar period as our campaigns (Joint et al., 1986, 2001; Rees et al., 1999; Lampert et al., 2002). There was considerable variation in phytoplankton areal biomass between campaigns (Figs. 9 and 10) and stations at the 
Table 4

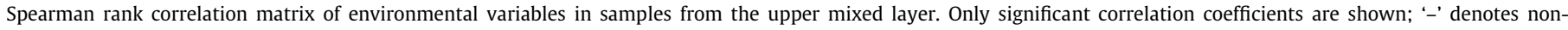
significant correlations.

\begin{tabular}{|c|c|c|c|c|c|c|c|c|c|c|c|c|c|c|c|}
\hline SST & MLD & $\begin{array}{l}\text { strat. } \\
\text { deg. }\end{array}$ & $\begin{array}{l}\text { nitracline } \\
\text { depth }\end{array}$ & $\begin{array}{l}\text { bottom } \\
\text { depth }\end{array}$ & $\mathrm{PO}_{4}$ & $\mathrm{NO}_{x}$ & $\mathrm{dSi}$ & $\mathrm{N}: \mathrm{P}$ & $\mathrm{dSi}: \mathrm{N}$ & chl $a$ & TEP & PIC & POC & $\mathrm{PN}$ & PIC:POC \\
\hline
\end{tabular}

\begin{tabular}{|c|c|c|c|c|c|c|c|c|c|c|c|c|c|c|c|c|}
\hline MLD & - & & & & & & & & & & & & & & & \\
\hline strat. deg. & 0.55 & -0.33 & & & & & & & & & & & & & & \\
\hline nitracline depth & - & -0.20 & 0.57 & & & & & & & & & & & & & \\
\hline bottom depth & - & - & -0.26 & -0.50 & & & & & & & & & & & & \\
\hline $\mathrm{PO}_{4}$ & -0.51 & 0.26 & -0.44 & -0.49 & 0.49 & & & & & & & & & & & \\
\hline $\mathrm{NO}_{x}$ & -0.51 & 0.42 & -0.47 & -0.62 & 0.41 & 0.83 & & & & & & & & & & \\
\hline $\mathrm{dSi}$ & - & 0.26 & -0.28 & -0.46 & 0.39 & 0.31 & 0.40 & & & & & & & & & \\
\hline $\mathrm{N}: \mathrm{P}$ & -0.26 & 0.39 & -0.30 & -0.59 & 0.22 & 0.35 & 0.77 & 0.29 & & & & & & & & \\
\hline dSi:N & 0.27 & - & - & - & - & -0.51 & -0.55 & 0.47 & -0.42 & & & & & & & \\
\hline $\operatorname{chl} a$ & - & - & - & - & - & - & - & 0.23 & - & 0.21 & & & & & & \\
\hline TEP & 0.48 & -0.33 & 0.39 & - & 0.23 & -0.28 & -0.30 & - & - & 0.35 & 0.42 & & & & & \\
\hline PIC & - & - & - & - & - & - & - & - & - & - & - & - & & & & \\
\hline POC & 0.34 & 0.26 & - & - & - & - & - & - & - & - & 0.34 & - & -0.37 & - & & \\
\hline PN & - & 0.26 & - & - & - & - & - & - & - & - & - & - & - & 0.68 & & \\
\hline PIC:POC & - & - & - & - & - & - & - & - & - & - & - & - & 0.96 & -0.55 & -0.30 & \\
\hline POC:PN & - & - & - & - & - & -0.25 & - & 0.26 & - & 0.49 & - & - & - & - & -0.57 & - \\
\hline
\end{tabular}
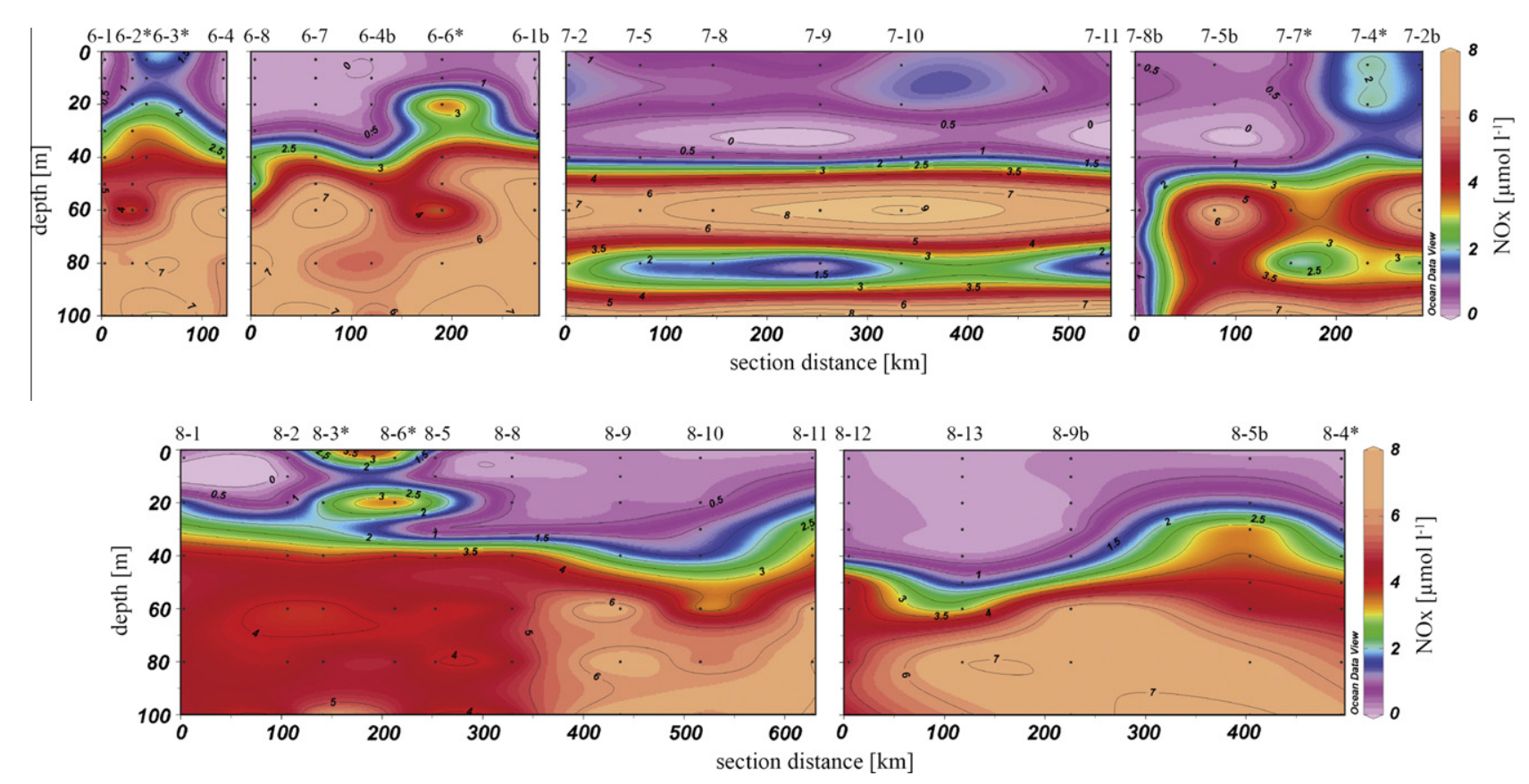

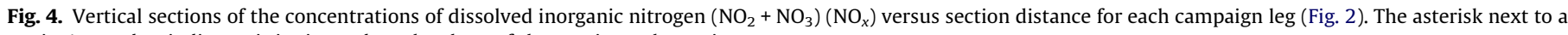
station's number indicates it is situated on the slope of the continental margin.

lower end of the chl $a$ range were generally encountered in 2007. The first leg of the 2007 campaign was characterised by storms with high wind speeds; this resulted in a pronounced deepening of the upper mixed layer ( $40 \pm 6 \mathrm{~m}$ in May versus $<10 \mathrm{~m}$ in April (Thyssen et al., 2009)) and thus partial dilution of the plankton biomass in waters which were already largely depleted of nutrients after the April blooms. Chlorophyll $a$ levels were also lower at many stations during the 2008 campaigns, most probably owing to overcast skies during the first 2 weeks of the campaigns, which may have slowed down bloom development (Figs. 9 and 10). The higher phytoplankton biomass ( $\mathrm{chl} a$ ) in June 2006 compared to the 2007 and 2008 campaigns may have been produced thanks to partial replenishment of depleted nutrient stocks due to a mixing event prior to the campaign. This mixing event is apparent from the deepening of the MLD and a drop in SST as described by Harlay et al. (2011) using modelled data by the UK Met Office National Centre for Ocean Forecasting for the North-East Atlantic. This partial supplementation of nutrients together with the prevailing high irradiance levels and SST during the 2006 campaign probably favoured phytoplankton growth (Figs. 3, 9 and 10, Tables 3 and SP5).

Given the enhanced vertical mixing and associated nutrient fluxes associated with the shelf edge, an increase in areal chl $a$ biomass across the continental slope could be expected. However, we did not find any differences in areal chl $a$ between the shelf and the slope stations (cf. Sharples et al., 2009) despite a significantly shallower nitracline and significantly higher inorganic $\mathrm{N}$ and $\mathrm{P}$ levels in the upper mixed layer of the slope stations (Figs. 4 and 5, Tables 3 and 4). This is most probably due to complex interplay between the dynamics of internal tidal mixing, mixed layer shoaling (higher on the shelf than the slope, Tables 3 and SP4), and meteorological conditions. Moreover, loss factors such as grazing (Holligan et al., 1993; Fileman et al., 2002; Painter et al., 2010b), viral lysis (Bratbak et al., 1996; Wilson et al., 2002) and enhanced export through aggregation (Boyd et al., 2005; Schmidt et al., in press) would further influence the distribution of phytoplankton biomass 

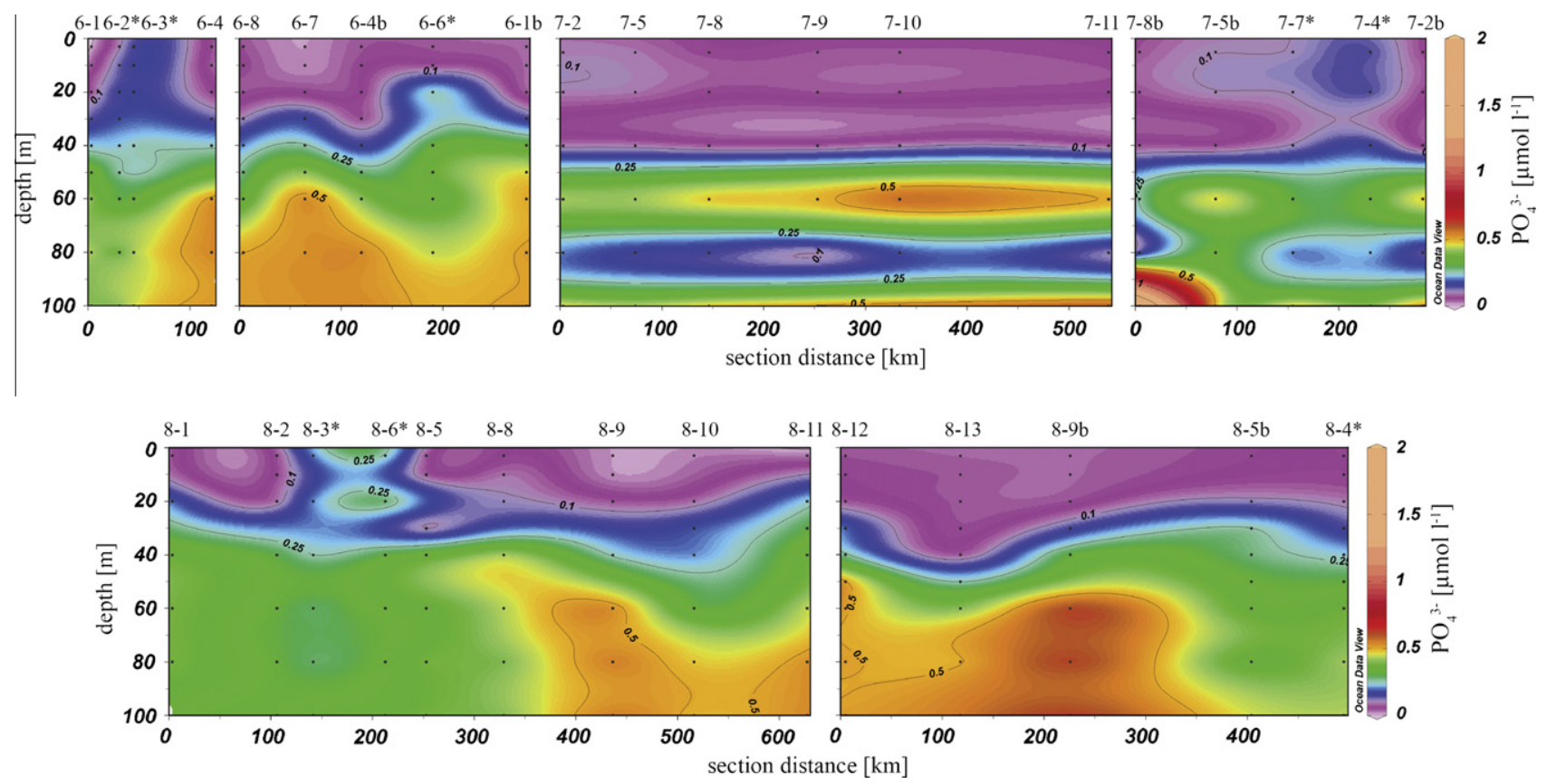

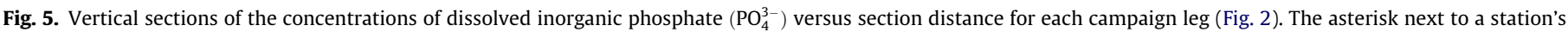
number indicates it is situated on the slope of the continental margin.

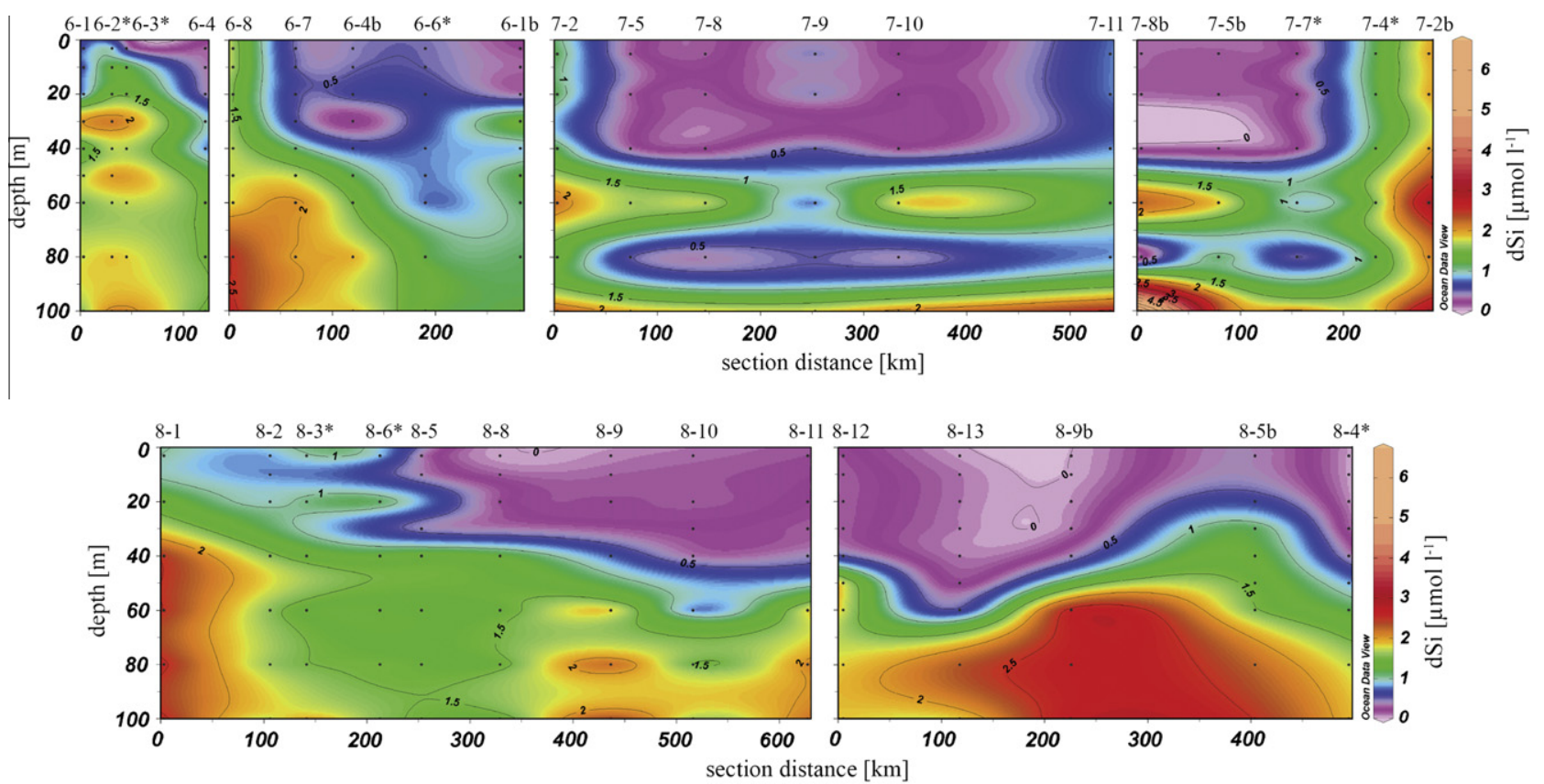

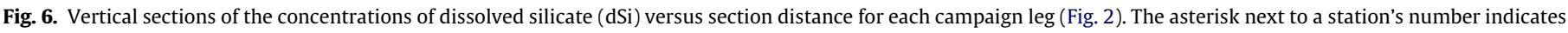
it is situated on the slope of the continental margin.

and its composition. In addition, changes in water circulation patterns and seasonal convective mixing intensity, influenced by meteorological conditions (Follows and Dutkiewicz, 2002; Henson et al., 2006) will also impact on horizontal heterogeneity in phytoplankton standing stocks.

\subsection{Thermal stratification of the water column and bloom progression}

We observed pronounced spatial and temporal variation in chl $a$ levels during each campaign which cannot readily be explained by linear relations with measured environmental variables (cf. Fig. 8 and Table 4). Stratification of the water column was not linearly related to biomass of any of the phytoplankton groups either. However, this may largely be due to the fact that biomass of total phytoplankton and the two most dominant groups, prymnesiophytes (i.e. coccolithophores) and diatoms, exhibit a unimodal-like relationship with stratification: highest biomass values are encountered at intermediate stratification $\left( \pm 4 \times 10^{-5} \mathrm{~s}^{-2}\right)$, although variation here can be high (Fig. 11). As shown by Schiebel and co-workers (Schiebel et al., 2011) relatively higher coccolithophore cell densities can occur under both well-mixed relatively high-nutrient conditions as well as under stratified low-nutrient conditions. Nonetheless, our 

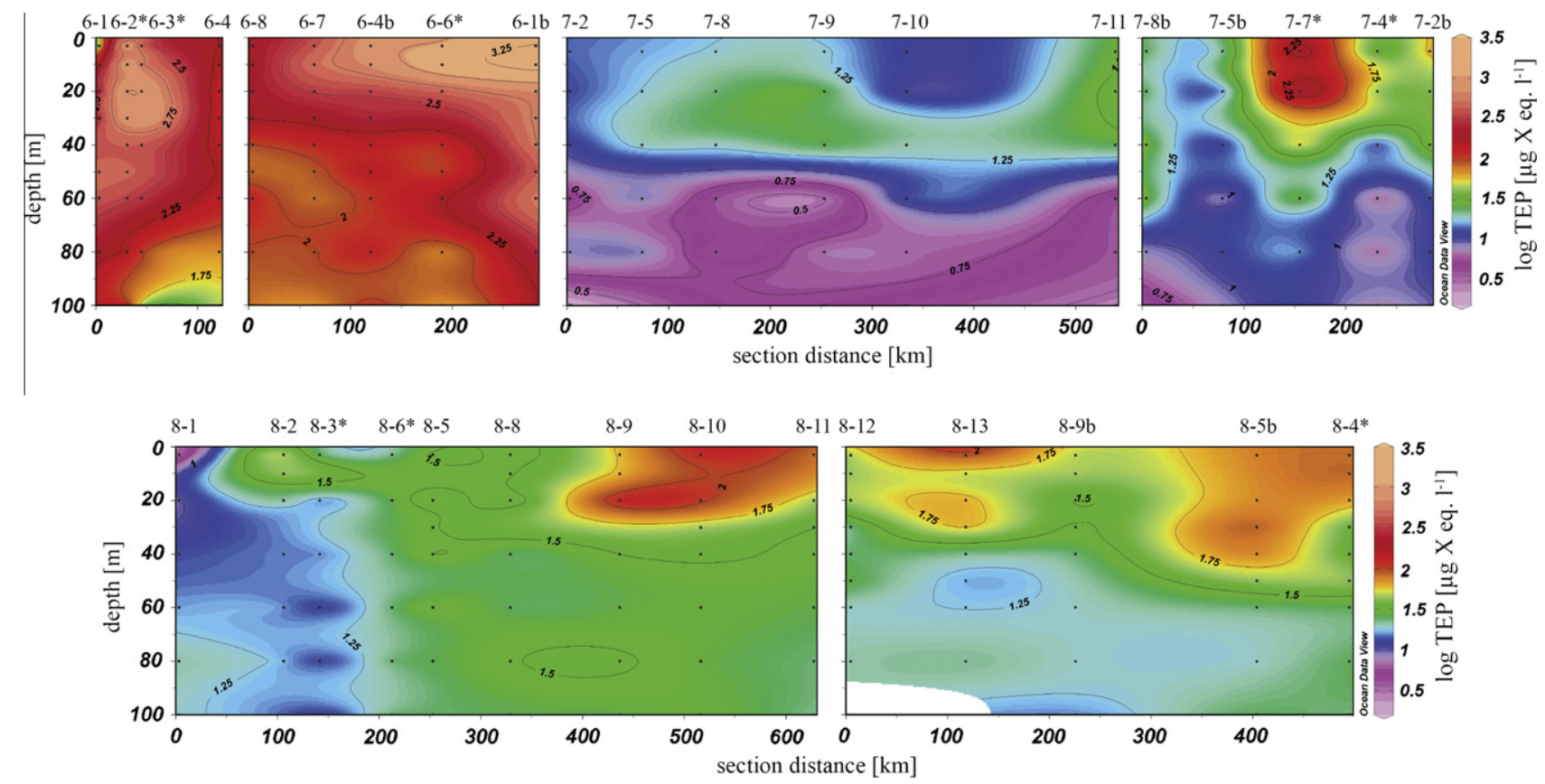

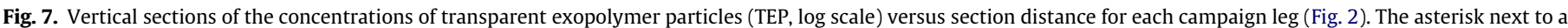
station's number indicates it is situated on the slope of the continental margin.

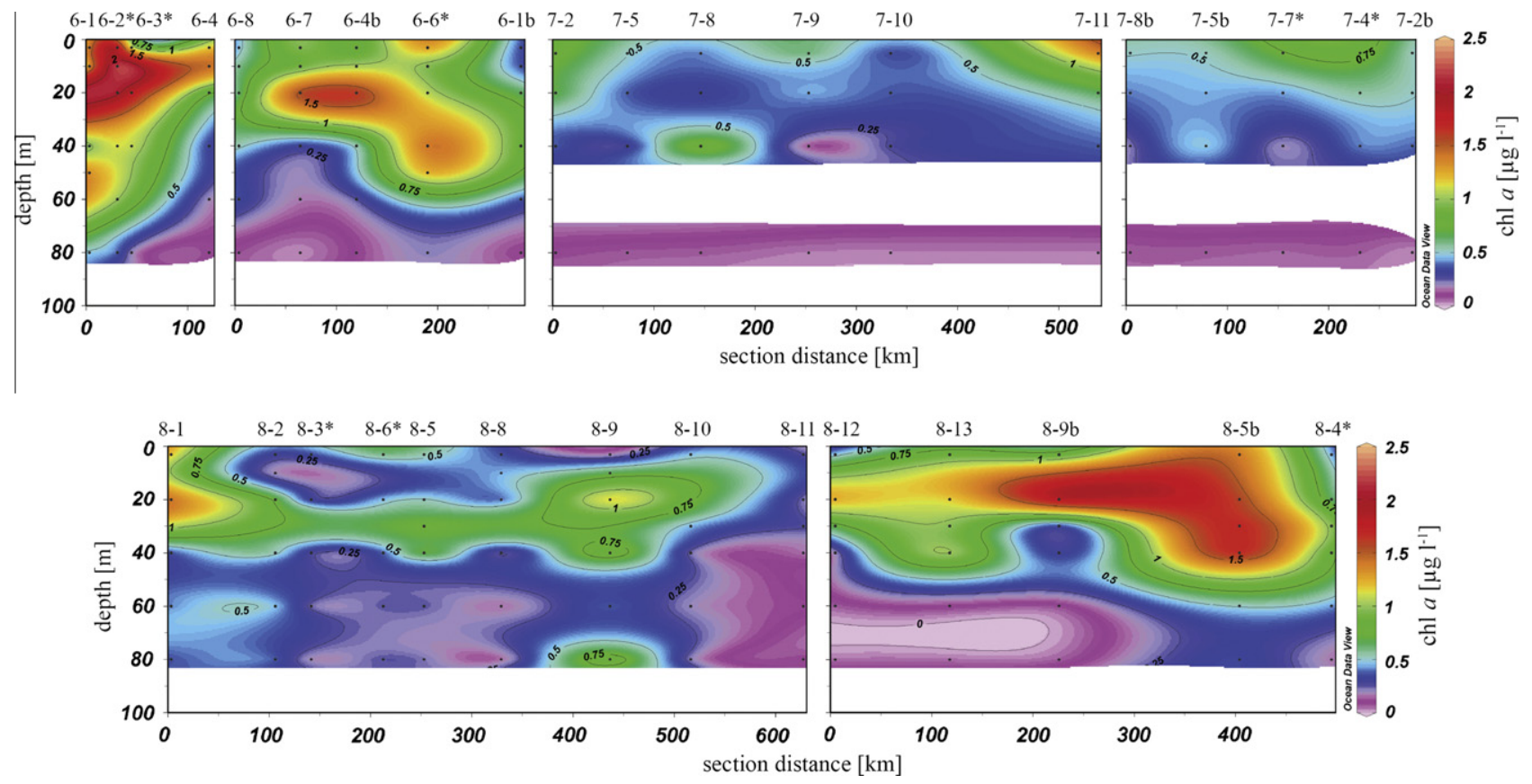

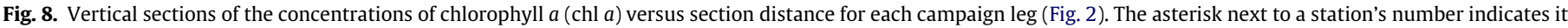
is situated on the slope of the continental margin.

data generally confirm the conceptual frame for phytoplankton bloom development and decline at the continental margin of the northern Bay of Biscay proposed by Harlay and co-workers (2011) on the basis of the 2006 data. Enhanced vertical mixing along the shelf edge (most probably as a result of internal tides) can lead to higher inorganic nutrient levels (N, P, dSi) and lower nitracline depth triggering mixed phytoplankton blooms, dominated by coccolithophores and/or diatoms. As the water masses are advected over the shelf they become more stratified and, as a result of phytoplankton growth, nutrients are being depleted (Table 3 ).

\subsection{Phytoplankton community structure}

The general scenario for phytoplankton bloom development and species succession in the NE Atlantic (Leblanc et al., 2009 and references therein): the replacement of early spring diatom blooms by coccolithophores, most probably occurs as a result of changing light conditions, mixed layer shoaling, and depletion of dSi levels (Boyd et al., 2010). Our data show that this generally accepted diatom-to-coccolithophore succession scenario is not universal, and that diatom and coccolithophore growth can 

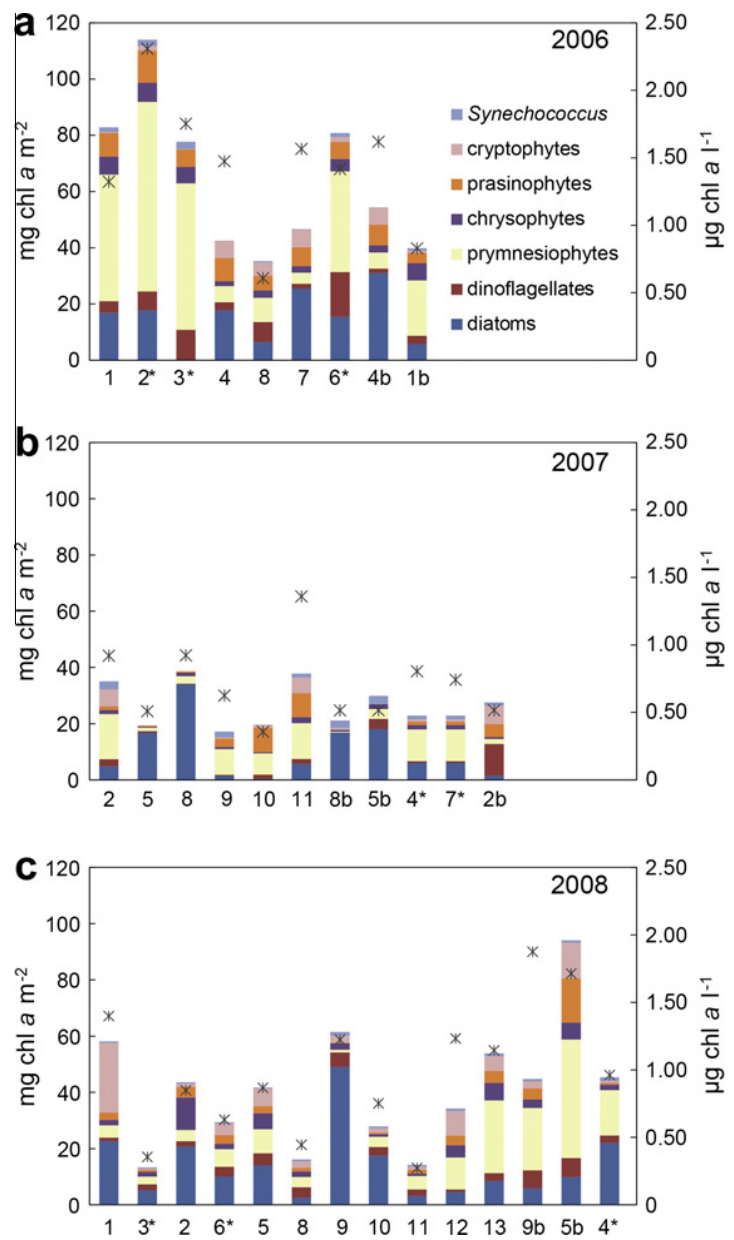

Fig. 9. Areal chl $a$ concentrations (upper $80 \mathrm{~m}$ of the water column) partitioned by CHEMTAX among the dominant phytoplankton groups identified for the stations visited in (a) June 2006, (b) May 2007, and (c) May 2008. The chl $a$ concentration at the depth of maximum chl $a$ concentration at each station is indicated by a cross. Stations are ordered chronologically and asterisks denote stations located on the slope of the continental shelf.

Table 5

Relative and absolute ( $\mathrm{chl} a$ ) abundance of phytoplankton groups as estimated by the CHEMTAX routine at the depth of chl $a$ maximum.

\begin{tabular}{llllllll}
\hline \multirow{2}{*}{ Phytoplankton group } & \multicolumn{3}{c}{ Relative abundance } & & \multicolumn{3}{c}{ Biomass $\left(\mu \mathrm{g} \mathrm{chl} a \mathrm{l}^{-1}\right)$} \\
\cline { 2 - 3 } & Max & Mean & SD & & Max & Mean & SD \\
\hline Diatoms & 0.89 & 0.29 & 0.27 & & 1.08 & 0.30 & 0.31 \\
Dinoflagellates & 0.69 & 0.09 & 0.09 & & 0.36 & 0.07 & 0.07 \\
Prymnesiophytes & 0.72 & 0.30 & 0.20 & & 1.57 & 0.32 & 0.37 \\
Chrysophytes s.l. & 0.20 & 0.07 & 0.04 & & 0.18 & 0.07 & 0.05 \\
Prasinophytes & 0.46 & 0.11 & 0.09 & & 0.38 & 0.11 & 0.10 \\
Cryptophytes & 0.60 & 0.12 & 0.12 & & 0.72 & 0.10 & 0.14 \\
Synechococcus & 0.32 & 0.03 & 0.05 & & 0.16 & 0.03 & 0.05 \\
\hline
\end{tabular}

alternate in the same area and during the same period despite low dSi levels (Figs. SP1 and SP2). This is further corroborated by the presence of surface diatom-dominated blooms at stations where drawdown of alkalinity had occurred and PIC had accumulated below the pycnocline, reminiscent of prior coccolithophorid calcification (Table SP5) (Suykens et al., 2010). Furthermore, our findings confirm previous reports (Barlow et al., 1993, 2002; Gibb et al., 2001; Joint et al., 2001; Lampert et al., 2002; Dandonneau et al., 2006; Leblanc et al., 2009) which show that the late spring blooms in the NE Atlantic are composed of mixed assemblages, dominated by diatoms and coccolithophores, but also with important contributions of prasinophytes and dinoflagellates.
The relative importance of coccolithophores and associated taxa versus diatoms during blooms was related to nutrient ratios (higher $\mathrm{N}: \mathrm{P}$ and low dSi:N values for coccolithophores, dinoflagellates and Synechococcus, and the inverse for diatoms, Table 7). Yet, the N:P ratio per se does not seem to determine absolute biomass development, and hence the magnitude of the blooms (see also Table 4). Our results are in general agreement with other studies investigating the conditions conducive to coccolithophore bloom development, such as a low dSi:N ratio, shallow mixed layer depth, and increased irradiances (Brown and Yoder, 1994; Painter et al., $2010 \mathrm{~b})$. A higher proportion of coccolithophore biomass was associated with higher $\mathrm{N}: \mathrm{P}$ ratios, even though these ratios were not that high (Table 3). The support for phosphate limitation (high inorganic $\mathrm{N}: \mathrm{P}$ ratios) for allowing coccolithophores to form blooms is not unequivocal as discussed by Lessard et al. (2005), who argumented that this was not a necessary condition (but compare with e.g. Tyrrell and Taylor (1996)).Emiliania huxleyi may be well-adapted to grow in low nutrient conditions, as it has been shown to have very high affinity for phosphate, and the ability to use organic nitrogen and phosphorus sources (Palenik and Henson, 1997; Riegman et al., 2000; Benner and Passow, 2010). It is likely that conflicting results regarding the necessary nutrient conditions may have been related to the high physiological and genetic variability between E. huxleyi strains, as has been shown for e.g. nitrogen use (Strom and Bright, 2009).

Our analyses further show that bloom development of coccolithophores and diatoms is independent of each other. The biomass of other, sometimes co-dominant phytoplankton groups was always significantly associated with coccolithophore blooms, not with diatoms. An anti-correlation between the biomass of phytoplankton groups would be expected when competitive exclusion takes place in a stable environment where the level or the stoichiometry of limiting resources such as nutrients favours the physiologically more adapted group. In a steady-state scenario, where nutrient levels are low, coccolithophores would be favoured by virtue of their lower half-saturation constants for nutrient uptake and small intracellular quotas (Tozzi et al., 2004). However, diatoms have been shown to outcompete e.g. coccolithophores in a situation where intermittent nutrient pulses are provided, such as is the case at the shelf break, thanks to their higher maximum nutrient uptake rates and storage capabilities potentially allowing them to sustain higher growth rates for several generations (Litchman et al., 2007; Cermeño et al., 2011).

The occurrence of diatom blooms at low dSi concentrations is surprising. These low levels of dSi encountered during the campaigns (median concentration in upper mixed layer: $0.45 \mu \mathrm{mol} \mathrm{l}^{-1}$ ) were probably the result of prior consumption by diatoms and thus did not favour further diatom growth to earlier spring bloom levels (Egge and Aksnes, 1992). While this may have led to the competitive advantage of coccolithophores and nanoplanktonic flagellates, it still does appear to allow more lightly silicified diatoms such as Rhizosolenia spp. to grow. Furthermore, the low surface $\mathrm{NO}_{x}$ levels at many stations may have actually favoured the appearance of diatom species which harbour diazotrophic symbionts, such as Rhizosolenia spp. and Chaetoceros spp. (Gomez et al., 2005; Bar Zeev et al., 2008). In that case their growth would have been limited by low $\mathrm{PO}_{4}$ and $\mathrm{dSi}$ concentrations rather than $\mathrm{NO}_{x}$, or possibly the availability of trace metals such as iron (Boyd et al., 2010), for which coccolithophores, on the other hand, were shown to have low requirements and high affinity (Sunda and Huntsman, 1995; Muggli and Harrison, 1996).

\subsection{Implications of phytoplankton community structure for carbon export}

Phytoplankton community structure has been shown to have an important impact on the fate of carbon in the ocean. Larger and 


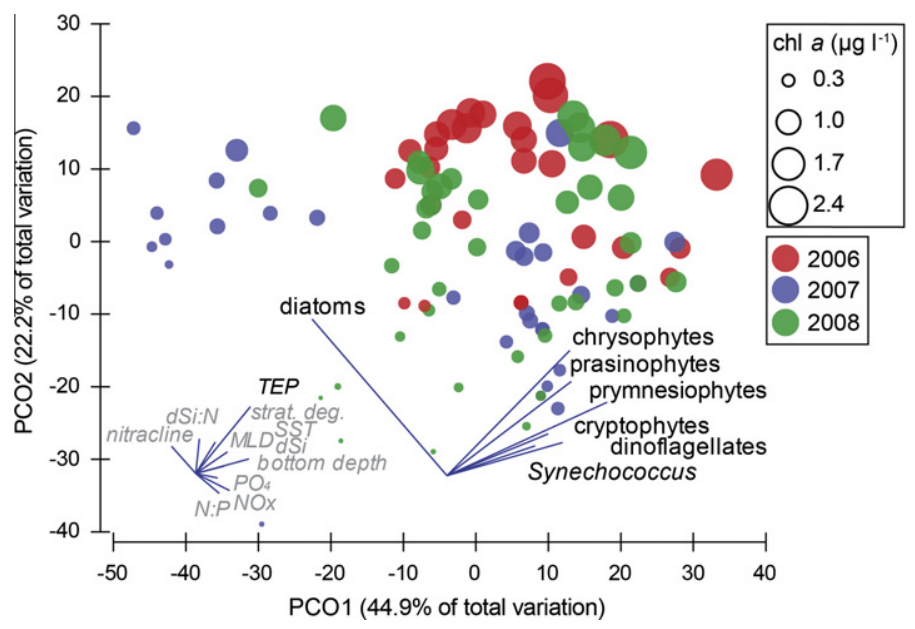

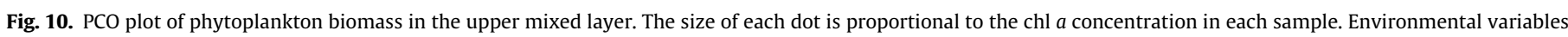

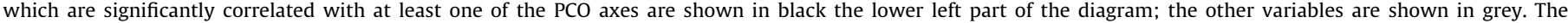
percentage of explained variance in the species data by the PCO axes is shown beside each axis.

Table 6

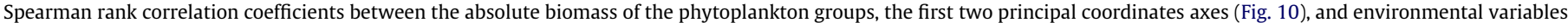
for all samples of the upper mixed layer. Only significant correlation coefficients are shown; '-' denotes non-significant correlations.

\begin{tabular}{|c|c|c|c|c|c|c|c|c|c|c|c|c|c|c|c|c|c|c|}
\hline & PCO1 & PCO2 & SST & MLD & $\begin{array}{l}\text { strat. } \\
\text { deg. }\end{array}$ & $\begin{array}{l}\text { nitracline } \\
\text { depth }\end{array}$ & $\begin{array}{l}\text { bottom } \\
\text { depth }\end{array}$ & $\mathrm{PO}_{4}$ & $\mathrm{NO}_{x}$ & $\mathrm{dSi}$ & $\mathrm{N}: \mathrm{P}$ & dSi:N & TEP & PIC & POC & PN & PIC:POC & POC:PN \\
\hline PCO1 & & & - & - & - & - & - & - & - & - & - & - & 0.32 & & & & & \\
\hline $\mathrm{PCO} 2$ & & & - & - & - & - & - & - & - & - & - & - & 0.26 & & & & & \\
\hline Diatoms & -0.64 & 0.73 & - & - & - & - & - & - & -0.23 & - & -0.20 & - & - & - & 0.24 & - & - & 0.24 \\
\hline Dinoflagellates & 0.54 & - & - & - & - & -0.21 & - & - & - & - & - & - & 0.32 & - & - & - & - & - \\
\hline Prymnesiophytes & 0.75 & 0.34 & - & - & - & - & - & - & - & - & - & - & 0.36 & - & - & - & - & - \\
\hline Chrysophytes & 0.58 & 0.59 & - & - & - & - & - & - & - & 0.25 & - & 0.28 & 0.50 & - & 0.27 & 0.24 & - & - \\
\hline Prasinophytes & 0.58 & 0.44 & - & - & - & - & - & - & - & 0.39 & - & 0.40 & 0.43 & - & - & - & - & - \\
\hline Cryptophytes & 0.48 & - & - & - & - & - & - & - & - & 0.28 & - & 0.38 & - & - & - & - & - & - \\
\hline Synechococcus & 0.41 & - & - & - & - & - & - & 0.21 & 0.24 & - & - & - & - & - & - & - & - & - \\
\hline$n$ Samples & 93 & 93 & 93 & 93 & 93 & 93 & 93 & 93 & 93 & 93 & 93 & 93 & 93 & 76 & 76 & 76 & 76 & 76 \\
\hline
\end{tabular}
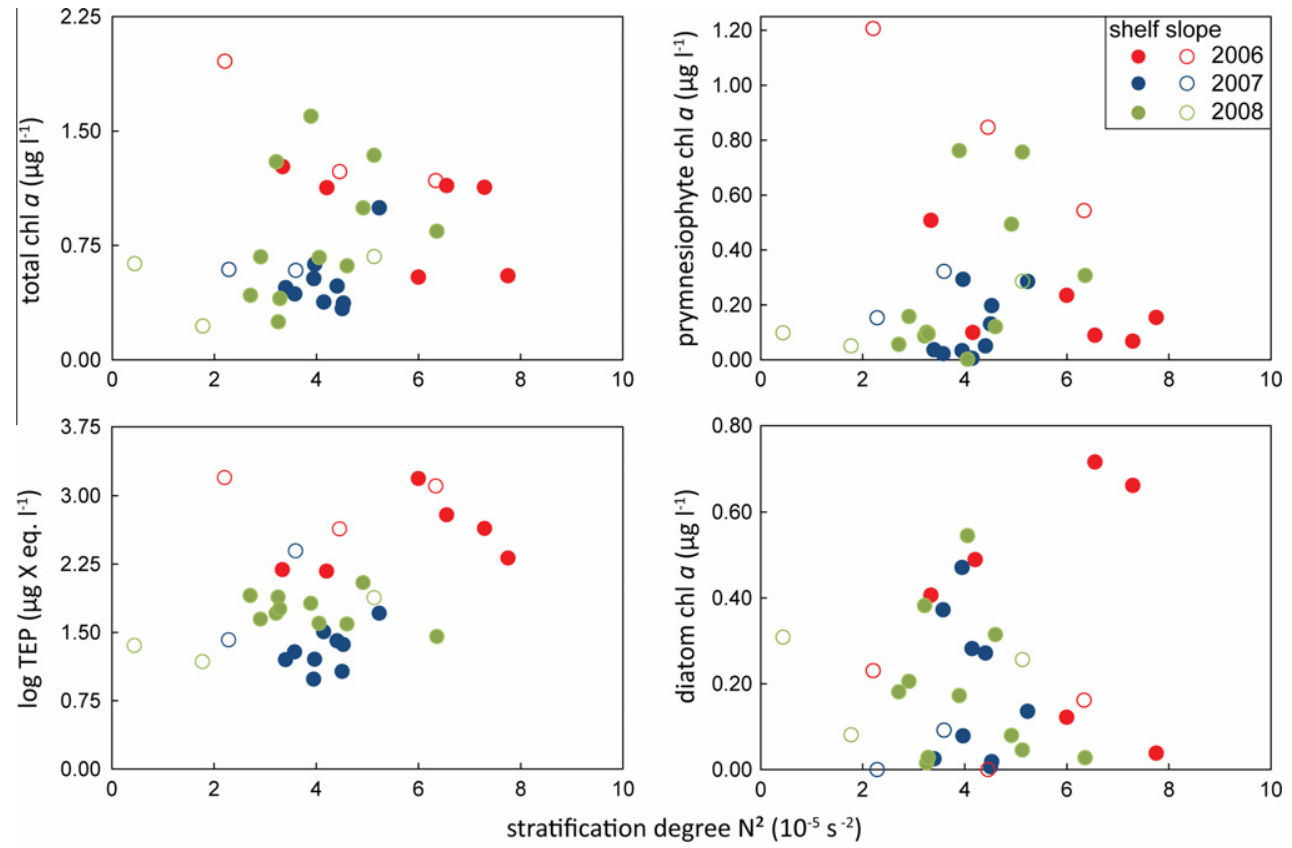

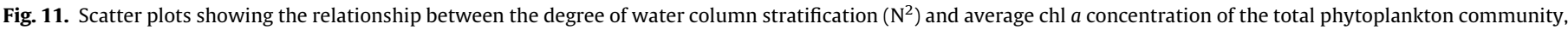
the diatoms, and the prymnesiophytes, and the log-transformed concentration of TEP in the upper mixed-layer on the shelf and slope side of the continental margin. 
Table 7

Spearman rank correlations between the relative biomass values of phytoplankton groups and ratios of dissolved nutrient concentrations and particulate materia concentrations for all samples with an above-median chl a concentration. Only significant correlation coefficients are shown; '-' denotes non-significant correlations.

\begin{tabular}{lllll}
\hline & $\mathrm{N}: \mathrm{P}$ & $\mathrm{dSi}: \mathrm{N}$ & $\mathrm{PIC}: \mathrm{POC}$ & $\mathrm{POC}: \mathrm{PN}$ \\
\hline Diatoms & -0.31 & 0.48 & - & 0.55 \\
Dinoflagellates & 0.31 & -0.60 & - & -0.57 \\
Prymnesiophytes & 0.38 & -0.50 & - & -0.40 \\
Chrysophytes & - & - & - & - \\
Prasinophytes & - & 0.59 & - & 0.36 \\
Cryptophytes & - & 0.34 & -0.39 & - \\
Synechococcus & 0.48 & -0.44 & - & - \\
$n$ Samples & 44 & 44 & 32 & 32 \\
\hline
\end{tabular}

heavier cells $(>10 \mu \mathrm{m})$ like diatoms may sink faster and may enhance the vertical transport of carbon (Michaels and Silver, 1988; Guidi et al., 2009), while they are also more efficiently grazed upon by larger zooplankton, such as copepods. Nanoplankton cells, such as coccolithophores, are thought to be more likely recycled in the microbial food web in the upper mixed layer and contribute less to vertical carbon export by sinking. However, as pointed out by Richardson and Jackson (2007), export efficiency of small plankton cells is likely greater than thought and can be enhanced by aggregation processes which could act as trophic lifts. Moreover, recent experiments comparing the effect of the incorporation of biogenic minerals from different sources into marine aggregates on their decomposition and sinking velocities have shown that ballasting by carbonate increased sinking velocities and reduced respiration rate compared to aggregates ballasted by opal (Iversen and Ploug, 2010). Leblanc et al. (2009) suggested sedimentation of diatoms in the form of aggregates based on the correspondence between TEP and biogenic silica at depth, while they also observed TEP associated with prymnesiophytes in the surface layer. They concluded that the relative contribution of diatoms and coccolithophores to carbon export in the North East Atlantic was still unresolved.

During our study, TEP concentrations were significantly correlated with coccolithophore and total phytoplankton biomass but not with diatoms (Fig. 10, Tables 4 and 6). TEP levels were highest when water column stratification was highest and nutrients depleted (Fig. 11 and Table 4). This was typically the case in June 2006 when we investigated the coccolithophorid blooms during their transition between growth and decline (Harlay et al., 2009). However, negative correlations between water column stratification and TEP micro concentration - determined using microscopy within individual campaigns may reflect processes such as aggregation or other loss processes (Harlay et al., 2011). Piontek et al. (2011) found significantly higher dissolved polysaccharide concentrations during the June 2006 campaign compared to May 2007, possibly pointing to their accumulation in surface waters due to exudation by phytoplankton and slow degradation by bacteria when nutrients are depleted. Coccolithophores and E. huxleyi in particular have been shown to potentially produce large amounts of TEP (Engel et al., 2004; Harlay et al., 2009), as have diatoms in diatom-dominated communities (Passow et al., 2001; Passow, $2002 \mathrm{~b}$ ). Moreover, the release of TEP precursors has been shown to occur in conditions of unbalanced growth of phytoplankton, when the cells excrete carbon rich material such as polysaccharides into the surrounding water due to lack of nutrients necessary for cell growth (Wood and Van Valen, 1990; Myklestad, 1995; Schartau et al., 2007). Accumulation of these precursors and their subsequent aggregation are responsible for the formation of TEP (Zhou et al., 1998; Passow, 2002a) and the production of coccoliths in itself may constitute a direct source of TEP (Godoi et al., 2009; Van Oostende et al., unpublished-b).
Even though we observed good congruence between high reflectance patches from remote sensing images and coccolithophore biomass (Fig. 3) (Harlay et al., 2009; Suykens et al., 2010), the lack of correlation between PIC and coccolithophore chl $a$ biomass (Tables 6 and 7) emphasises the temporal and spatial (vertical) decoupling between the accumulation of biomass and the accumulation of coccoliths associated with cells or shed during the calcification phase of the bloom (Beaufort and Heussner, 1999). Interestingly, PIC had accumulated below the pycnocline at certain stations (6-4, 6-4b, 6-7, 6-8, 7-2b, 7-4, 7-5, 8-9, 8-10), which together with the draw-down of total alkalinity by calcification is indicative of prior pelagic calcification (Suykens et al., 2010). However, we cannot exclude the contribution of lithogenic material to PIC near the bottom of the water column where resuspension of the sediment is possible (Daniels et al., 2012). Therefore, as reported before (Poulton et al., 2007; Leblanc et al., 2009), PIC concentration is probably not a good indicator of in situ coccolithophore biomass but rather is an accumulative signal of present and prior calcification activity on short temporal time scale. This temporal decoupling is further complicated by TEP-mediated aggregation of coccoliths or their incorporation into faecal pellets after grazing, promoting the rapid disappearance of high reflectance remote sensing patches and potentially enhancing carbon export efficiency due to increased sinking velocity (De La Rocha and Passow, 2007; Harlay et al., 2009; Iversen and Ploug, 2010).

\section{Conclusions}

The recurrent scenario emerging from previous studies is that diatoms dominate the main spring bloom event, sometimes cooccurring with prymnesiophytes or dinoflagellates, and tend to be outcompeted by prymnesiophytes during later stages of the spring bloom in the North East Atlantic (Leblanc et al., 2009). Yet we showed that, during later blooms, diatom and coccolithophore can co-occur and their growth can alternate in the same area and during the same period. Alternation between diatom and coccolithophorid blooms of similar magnitude following the main spring bloom was partly driven by changes in nutrient stoichiometry ( $\mathrm{N}: \mathrm{P}$ and dSi:N). Furthermore, high TEP concentrations associated with nutrient-depleted, coccolithophore-rich water masses could facilitate the disappearance of the bloom and enhance the production export through aggregation and ballasting mechanisms. Thus, phytoplankton community structure and composition would not only affect the cell size distribution but also the carbon export efficiency. Variation in bloom magnitude during and between our campaigns was ascribed to different conditions of temperature, irradiance, and wind-driven mixing of the surface layer during or preceding the campaigns. However, the high (sub-) mesoscale heterogeneity in phytoplankton bloom stage and composition during each campaign was probably caused by the interplay of enhanced vertical mixing at the slope of the continental margin and the thermal stratification of the water masses during advection away from the continental slope. Further studies combining in situ measurements of plankton species abundance and particle traps with high-resolution remote sensing images to differentiate phytoplankton groups (e.g. PHYSAT, see Alvain et al. (2008)) and the use of altimetry-derived Lagrangian diagnostics of the surface transport (d'Ovidio et al., 2010) could greatly improve our understanding of phytoplankton bloom dynamics and its potential control on the biological carbon pump in areas of important biogeochemical cycling such as the continental margins.

\section{Acknowledgments}

The authors sincerely thank the officers and crew members of the R.V. Belgica for their logistic support during the campaigns. J. 
Backers, J.-P. De Blauw, and G. Deschepper of the Unit of the North Sea Mathematical Models (Brussels/Ostend, Belgium) are acknowledged for their support in data acquisition during the field campaigns. We are grateful to C. Souffreau, A. De Wever, and D. De Bock for their assistance during sample collection and to F. Steen and N. Breine for performing the optical microscopy analyses. We thank I. Daveloose and R. Dasseville for help with the HPLC analyses, C. De Bodt for TEP concentration measurements and N. Roevros for performing nutrient analyses. Finally we thank two anonymous reviewers for their constructive comments. This study was financed by Belgian Federal Science Policy Office in the framework of the PEACE project (Contract Numbers SD/CS/03A and SD/CS/03B). N. Van Oostende received a PhD Grant from the agency for Innovation by Science and Technology (IWT-Flanders).

\section{Appendix A. Supplementary material}

Supplementary data associated with this article can be found, in the online version, at http://dx.doi.org/10.1016/j.pocean.2012.04. 016.

\section{References}

Alvain, S., Moulin, C., Dandonneau, Y., Loisel, H., 2008. Seasonal distribution and succession of dominant phytoplankton groups in the global ocean: a satellite view. Global Biogeochemical Cycles 22, 15

Andersen, R.A., Bidigare, R.R., Keller, M.D., Latasa, M., 1996. A comparison of HPLC pigment signatures and electron microscopic observations for oligotrophic waters of the North Atlantic and Pacific Oceans. Deep Sea Research Part II Topical Studies in Oceanography 43, 517-537.

Anderson, M.J., Robinson, J., 2003. Generalized discriminant analysis based on distances. Australian and New Zealand Journal of Statistics 45, 301-318.

Anderson, M.J., Gorley, R.N., Clarke, K.R. (Eds.), 2008. PERMANOVA+ for PRIMER: Guide to Software and Statistical Methods. PRIMER-E, Plymouth, UK.

Armstrong, R.A., Lee, C., Hedges, J.I., Honjo, S., Wakeham, S.G., 2002. A new, mechanistic model for organic carbon fluxes in the ocean based on the quantitative association of POC with ballast minerals. Deep-Sea Research Part II - Topical Studies in Oceanography 49, 219-236.

Bar Zeev, E., Yogev, T., Man-Aharonovich, D., Kress, N., Herut, B., Beja, O., BermanFrank, I., 2008. Seasonal dynamics of the endosymbiotic, nitrogen-fixing cyanobacterium Richelia intracellularis in the eastern Mediterranean Sea. Isme Journal 2, 911-923.

Barlow, R.G., Mantoura, R.F.C., Gough, M.A., Fileman, T.W., 1993. Pigment signatures of the phytoplankton composition in the northeastern Atlantic during the 1990 spring bloom. Deep-Sea Research Part II - Topical Studies in Oceanography 40, 459-477.

Barlow, R.G., Aiken, J., Holligan, P.M., Cummings, D.G., Maritorena, S., Hooker, S., 2002. Phytoplankton pigment and absorption characteristics along meridional transects in the Atlantic Ocean. Deep-Sea Research Part I - Oceanographic Research Papers 49, 637-660.

Beaufort, L., Heussner, S., 1999. Coccolithophorids on the continental slope of the Bay of Biscay - production, transport and contribution to mass fluxes. Deep- Sea Research Part II - Topical Studies in Oceanography 46, 2147-2174.

Behrenfeld, M.J., 2010. Abandoning Sverdrup's Critical Depth Hypothesis on phytoplankton blooms. Ecology 91, 977-989.

Benner, I., Passow, U., 2010. Utilization of organic nutrients by coccolithophores. Marine Ecology - Progress Series 404, 21-29.

Bidigare, R.R., Van Heukelem, L., Trees, C.C., 2005. Analysis of Algal Pigments by High-Performance Liquid Chromatography. Academic Press.

Bollmann, J., Cortes, M.Y., Haidar, A.T., Brabec, B., Close, A., Hofmann, R., Palma, S., Tupas, L., Thierstein, H.R., 2002. Techniques for quantitative analyses of calcareous marine phytoplankton. Marine Micropaleontology 44, 163-185.

Boyd, P.W., Strzepek, R., Takeda, S., Jackson, G., Wong, C.S., McKay, R.M., Law, C., Kiyosawa, H., Saito, H., Sherry, N., Johnson, K., Gower, J., Ramaiah, N., 2005. The evolution and termination of an iron-induced mesoscale bloom in the northeast subarctic Pacific. Limnology and Oceanography 50, 1872-1886.

Boyd, P.W., Strzepek, R., Fu, F.X., Hutchins, D.A., 2010. Environmental control of open-ocean phytoplankton groups: now and in the future. Limnology and Oceanography 55, 1353-1376.

Bratbak, G., Wilson, W., Heldal, M., 1996. Viral control of Emiliania huxleyi blooms? Journal of Marine Systems 9, 75-81.

Brown, C.W., Yoder, J.A., 1994. Coccolithophorid blooms in the global ocean. Journal of Geophysical Research - Oceans 99, 7467-7482.

Brussaard, C.P.D., 2004. Viral control of phytoplankton populations - a review. Journal of Eukaryotic Microbiology 51, 125-138.

Burkill, P.H., Archer, S.D., Robinson, C., Nightingale, P.D., Groom, S.B., Tarran, G.A., Zubkov, M.V., 2002. Dimethyl sulphide biogeochemistry within a coccolithophore bloom (DISCO): an overview. Deep-Sea Research Part II Topical Studies in Oceanography 49, 2863-2885.
Calbet, A., Landry, M.R., 2004. Phytoplankton growth, microzooplankton grazing, and carbon cycling in marine systems. Limnology and Oceanography 49, 5157.

Cermeño, P., Dutkiewicz, S., Harris, R.P., Follows, M., Schofield, O., Falkowski, P.G., 2008. The role of nutricline depth in regulating the ocean carbon cycle. Proceedings of the National Academy of Sciences of the United States of America 105, 20344-20349.

Cermeño, P., Lee, J.-B., Wyman, K., Schofield, O., Falkowski, P.G., 2011. Competitive dynamics in two species of marine phytoplankton under non-equilibrium conditions. Marine Ecology - Progress Series 429, 19-28.

Clarke, K.R., Gorley, R.N., 2006. PRIMER v6: User Manual/Tutorial. PRIMER-E Ltd.

d'Ovidio, F., De Monte, S., Alvain, S., Dandonneau, Y., Lévy, M., 2010. Fluid dynamical niches of phytoplankton types. Proceedings of the National Academy of Sciences of the United States of America 107, 18366-18370.

Dandonneau, Y., Montel, Y., Blanchot, J., Giraudeau, J., Neveux, J., 2006. Temporal variability in phytoplankton pigments, picoplankton and coccolithophores along a transect through the North Atlantic and tropical southwestern Pacific. Deep-Sea Research Part I - Oceanographic Research Papers 53, 689-712.

Daniels, C.J., Tyrrell, T., Poulton, A.J., Pettit, L., 2012. The influence of lithogenic material on particulate inorganic carbon measurements of coccolithophores in the Bay of Biscay. Limnology and Oceanography 57, 145-153.

De La Rocha, C.L., Passow, U., 2007. Factors influencing the sinking of POC and the efficiency of the biological carbon pump. Deep-Sea Research Part II - Topical Studies in Oceanography 54, 639-658.

Egge, J.K., Aksnes, D.L., 1992. Silicate as regulating nutrient in phytoplankton competition. Marine Ecology - Progress Series 83, 281-289.

Engel, A., Delille, B., Jacquet, S., Riebesell, U., Rochelle-Newall, E., Terbruggen, A. Zondervan, I., 2004. Transparent exopolymer particles and dissolved organic carbon production by Emiliania huxleyi exposed to different $\mathrm{CO}_{2}$ concentrations: a mesocosm experiment. Aquatic Microbial Ecology 34, 93-104.

Fileman, E.S., Cummings, D.G., Llewellyn, C.A., 2002. Microplankton community structure and the impact of microzooplankton grazing during an Emiliania huxleyi bloom, off the Devon coast. Journal of the Marine Biological Association of the United Kingdom 82, 359-368.

Finkel, Z.V., Beardall, J., Flynn, K.J., Quigg, A., Rees, T.A.V., Raven, J.A., 2010. Phytoplankton in a changing world: cell size and elemental stoichiometry. Journal of Plankton Research 32, 119-137.

Follows, M., Dutkiewicz, S., 2002. Meteorological modulation of the North Atlantic spring bloom. Deep-Sea Research Part II - Topical Studies in Oceanography 49 321-344.

Gibb, S.W., Cummings, D.G., Irigoien, X., Barlow, R.G., Fauzi, R., Mantoura, C., 2001. Phytoplankton pigment chemotaxonomy of the northeastern Atlantic. Deep-Sea Research Part II - Topical Studies in Oceanography 48, 795-823.

Godoi, R.H.M., Aerts, K., Harlay, J., Kaegi, R., Ro, C.U., Chou, L., Van Grieken, R., 2009 Organic surface coating on Coccolithophores - Emiliania huxleyi: its determination and implication in the marine carbon cycle. Microchemical Journal 91, 266-271.

Gomez, F., Furuya, K., Takeda, S., 2005. Distribution of the cyanobacterium Richelia intracellularis as an epiphyte of the diatom Chaetoceros compressus in the western Pacific Ocean. Journal of Plankton Research 27, 323-330.

Grasshoff, K., Ehrhardt, M., Kremling, K. (Eds.), 1983. Methods of Seawater Analysis. Verlag Chemie.

Guidi, L., Stemmann, L., Jackson, G.A., Ibanez, F., Claustre, H., Legendre, L., Picheral, M., Gorsky, G., 2009. Effects of phytoplankton community on production, size and export of large aggregates: a world-ocean analysis. Limnology and Oceanography 54, 1951-1963.

Harlay, J., De Bodt, C., Engel, A., Jansen, S., d'Hoop, Q., Piontek, J., Van Oostende, N., Groom, S., Sabbe, K., Chou, L., 2009. Abundance and size distribution of transparent exopolymer particles (TEP) in a coccolithophorid bloom in the northern Bay of Biscay. Deep-Sea Research Part I - Oceanographic Research Papers 56, 1251-1265.

Harlay, J., Borges, A.V., Van der Zee, C., Delille, B., Godoi, R.H.M., Schiettecatte, L.S. Roevros, N., Aerts, K., Lapernat, P.E., Rebreanu, L., Groom, S., Daro, M.H., Van Grieken, R., Chou, L., 2010. Biogeochemical study of a coccolithophore bloom in the northern Bay of Biscay (NE Atlantic Ocean) in June 2004. Progress in Oceanography 86, 317-336.

Harlay, J., Chou, L., De Bodt, C., Van Oostende, N., Piontek, J., Suykens, K., Engel, A., Sabbe, K., Groom, S., Delille, B., Borges, A.V., 2011. Biogeochemistry and carbon mass balance of a coccolithophore bloom in the northern Bay of Biscay (June 2006). Deep Sea Research Part I - Oceanographic Research Papers 58, 111-127.

Hasle, G.R., Syvertsen, E.E., 1997. Marine diatoms. In: Tomas, C.R. (Ed.), Identifying Marine Phytoplankton. Academic Press Inc., San Diego, pp. 5-385.

Havskum, H., Schlüter, L., Scharek, R., Berdalet, E., Jacquet, S., 2004. Routine quantification of phytoplankton groups - microscopy or pigment analyses? Marine Ecology - Progress Series 273, 31-42.

Head, R.N., Crawford, D.W., Egge, J.K., Harris, R.P., Kristiansen, S., Lesley, D.J., Maranon, E., Pond, D., Purdie, D.A., 1998. The hydrography and biology of a bloom of the coccolithophorid Emiliania huxleyi in the northern North Sea. Journal of Sea Research 39, 255-266.

Heimdal, B.R., 1997. Modern coccolithophorids. In: Tomas, C.R. (Ed.), Identifying Marine Phytoplankton. Academic Press Inc., San Diego, pp. 731-832.

Henson, S.A., Robinson, I., Allen, J.T., Waniek, J.J., 2006. Effect of meteorological conditions on interannual variability in timing and magnitude of the spring bloom in the Irminger Basin, North Atlantic. Deep-Sea Research Part I Oceanographic Research Papers 53, 1601-1615. 
Holligan, P.M., Groom, S.B., 1986. Phytoplankton distributions along the shelf break. Proceedings of the Royal Society of Edinburgh Section B - Biological Sciences 88, 239-263.

Holligan, P.M., Fernandez, E., Aiken, J., Balch, W.M., Boyd, P., Burkill, P.H., Finch, M., Groom, S.B., Malin, G., Muller, K., Purdie, D.A., Robinson, C., Trees, C.C., Turner, S.M., Vanderwal, P., 1993. A biogeochemical study of the coccolithophore, Emiliania huxleyi, in the North-Atlantic. Global Biogeochemical Cycles 7, 879-900.

Huthnance, J.M., Coelho, H., Griffiths, C.R., Knight, P.J., Rees, A.P., Sinha, B., Vangriesheim, A., White, M., Chatwin, P.G., 2001. Physical structures, advection and mixing in the region of Goban spur. Deep-Sea Research Part II - Topical Studies in Oceanography 48, 2979-3021.

Irigoien, X., Meyer, B., Harris, R., Harbour, D., 2004. Using HPLC pigment analysis to investigate phytoplankton taxonomy: the importance of knowing your species. Helgoland Marine Research 58, 77-82.

Iversen, M.H., Ploug, H., 2010. Ballast minerals and the sinking carbon flux in the ocean: carbon-specific respiration rates and sinking velocity of marine snow aggregates. Biogeosciences 7, 2613-2624.

Jeffrey, S.W., Mantoura, R.F.C., 1997. Pigment abbreviations used by SCOR Working Group 78. In: Jeffrey, S.W., Mantoura, R.F.C., Wright, S.W. (Eds.), Phytoplankton Pigments in Oceanography: Guidelines to Modern Methods. UNESCO Publishing, pp. 564-565.

Ji, R.B., Edwards, M., Mackas, D.L., Runge, J.A., Thomas, A.C., 2010. Marine plankton phenology and life history in a changing climate: current research and future directions. Journal of Plankton Research 32, 1355-1368.

Johnsen, G., Sakshaug, E., 1993. Biooptical characteristics and photoadaptive responses in the toxic and bloom-forming dinoflagellates Gyrodinium aureolum, Gymnodinium galatheanum, and 2 strains on Prorocentrum minimum. Journal of Phycology 29, 627-642.

Joint, I., Wollast, R., Chou, L., Batten, S., Elskens, M., Edwards, E., Hirst, A., Burkill, P. Groom, S., Gibb, S., Miller, A., Hydes, D., Dehairs, F., Antia, A., Barlow, R., Rees, A., Pomroy, A., Brockmann, U., Cummings, D., Lampitt, R., Loijens, M., Mantoura, F. Miller, P., Raabe, T., Alvarez-Salgado, X., Stelfox, C., Woolfenden, J., 2001. Pelagic production at the Celtic Sea shelf break. Deep-Sea Research Part II - Topical Studies in Oceanography 48, 3049-3081.

Joint, I.R., Owens, N.J.P., Pomroy, A.J., 1986. Seasonal production of photosynthetic picoplankton and nanoplankton in the Celtic Sea. Marine Ecology - Progress Series 28, 251-258.

Lampert, L., Queguiner, B., Labasque, T., Pichon, A., Lebreton, N., 2002. Spatial variability of phytoplankton composition and biomass on the eastern continental shelf of the Bay of Biscay (north-east Atlantic Ocean). Evidence for a bloom of Emiliania huxleyi (Prymnesiophyceae) in spring 1998. Continenta Shelf Research 22, 1225-1247.

Landry, M.R., Ohman, M.D., Goericke, R., Stukel, M.R., Tsyrklevich, K., 2009. Lagrangian studies of phytoplankton growth and grazing relationships in a coastal upwelling ecosystem off Southern California. Progress in Oceanography $83,208-216$

Latasa, M., Scharek, R., Le Gall, F., Guillou, L., 2004. Pigment suites and taxonomic groups in Prasinophyceae. Journal of Phycology 40, 1149-1155.

Latasa, M., 2007. Improving estimations of phytoplankton class abundances using CHEMTAX. Marine Ecology - Progress Series 329, 13-21.

Leblanc, K., Hare, C.E., Feng, Y., Berg, G.M., DiTullio, G.R., Neeley, A., Benner, I. Sprengel, C., Beck, A., Sanudo-Wilhelmy, S.A., Passow, U., Klinck, K., Rowe, J.M. Wilhelm, S.W., Brown, C.W., Hutchins, D.A., 2009. Distribution of calcifying and silicifying phytoplankton in relation to environmental and biogeochemical parameters during the late stages of the 2005 North East Atlantic Spring Bloom. Biogeosciences 6, 2155-2179.

Lessard, E.J., Merico, A., Tyrrell, T., 2005. Nitrate: phosphate ratios and Emiliania huxleyi blooms. Limnology and Oceanography 50, 1020-1024.

Litchman, E., Klausmeier, C.A., Schofield, O.M., Falkowski, P.G., 2007. The role of functional traits and trade-offs in structuring phytoplankton communities: scaling from cellular to ecosystem level. Ecology Letters 10,1170-1181.

Liu, H.B., Bidigare, R.R., Laws, E., Landry, M.R., Campbell, L., 1999. Cell cycle and physiological characteristics of Synechococcus (WH7803) in chemostat culture. Marine Ecology - Progress Series 189, 17-25.

Llewellyn, C.A., Gibb, S.W., 2000. Intra-class variability in the carbon, pigment and biomineral content of prymnesiophytes and diatoms. Marine Ecology - Progress Series 193, 33-44.

Lochte, K., Ducklow, H.W., Fasham, M.J.R., Stienen, C., 1993. Plankton succession and carbon cycling at $47^{\circ} \mathrm{N}-20^{\circ} \mathrm{W}$ during the JGOFS North-Atlantic bloom experiment. Deep-Sea Research Part II - Topical Studies in Oceanography 40, 91-114.

Mackey, M.D., Mackey, D.J., Higgins, H.W., Wright, S.W., 1996. CHEMTAX - a program for estimating class abundances from chemical markers: application to HPLC measurements of phytoplankton. Marine Ecology - Progress Series 144, 265-283.

Michaels, A.F., Silver, M.W., 1988. Primary production, sinking fluxes and the microbial food web. Deep-Sea Research Part A - Oceanographic Research Papers 35, 473-490.

Millard, R.C., Owens, W.B., Fofonoff, N.P., 1990. On the calculation of the BruntVäisälä frequency. Deep-Sea Research Part I - Oceanographic Research Papers 37, 167-181.

Muggli, D.L., Harrison, P.J., 1996. EDTA suppresses the growth of oceanic phytoplankton from the Northeast Subarctic Pacific. Journal of Experimental Marine Biology and Ecology 205, 221-227.

Myklestad, S.M., 1995. Release of extracellular products by phytoplankton with special emphasis on polysaccharides. Science of the Total Environment 165 155-164.
Nanninga, H.J., Tyrrell, T., 1996. Importance of light for the formation of algal blooms by Emiliania huxleyi. Marine Ecology - Progress Series 136, 195-203.

Painter, S.C., Lucas, M.I., Stinchcombe, M.C., Bibby, T.S., Poulton, A.J., 2010a. Summertime trends in pelagic biogeochemistry at the Porcupine Abyssal Plain study site in the northeast Atlantic. Deep-Sea Research Part II - Topical Studies in Oceanography 57, 1313-1323.

Painter, S.C., Poulton, A.J., Allen, J.T., Pidcock, R., Balch, W.M., 2010b. The COPAS'08 expedition to the Patagonian Shelf Physical and environmental conditions during the 2008 coccolithophore bloom. Continental Shelf Research 30, 19071923.

Palenik, B., Henson, S.E., 1997. The use of amides and other organic nitrogen sources by the phytoplankton Emiliania huxleyi. Limnology and Oceanography 42, 1544-1551.

Passow, U., Alldredge, A.L., 1995. A dye-binding assay for the spectrophotometric measurement of transparent exopolymer particles (TEP). Limnology and Oceanography 40, 1326-1335.

Passow, U., Shipe, R.F., Murray, A., Pak, D.K., Brzezinski, M.A., Alldredge, A.L., 2001. The origin of transparent exopolymer particles (TEP) and their role in the sedimentation of particulate matter. Continental Shelf Research 21, 327346.

Passow, U., 2002a. Production of transparent exopolymer particles (TEP) by phytoand bacterioplankton. Marine Ecology - Progress Series 236, 1-12.

Passow, U., 2002b. Transparent exopolymer particles (TEP) in aquatic environments. Progress in Oceanography 55, 287-333.

Pingree, R.D., Lecann, B., 1989. Celtic and Armorican slope and shelf residual currents. Progress in Oceanography 23, 303-338.

Piontek, J., Handel, N., De Bodt, C., Harlay, J., Chou, L., Engel, A., 2011. The utilization of polysaccharides by heterotrophic bacterioplankton in the Bay of Biscay (North Atlantic Ocean). Journal of Plankton Research 33, 1719-1735.

Poulton, A.J., Adey, T.R., Balch, W.M., Holligan, P.M., 2007. Relating coccolithophore calcification rates to phytoplankton community dynamics: regional differences and implications for carbon export. Deep-Sea Research Part II - Topical Studies in Oceanography 54, 538-557.

Poulton, A.J., Charalampopoulou, A., Young, J.R., Tarran, G.A., Lucas, M.I., Quartly, G.D., 2010. Coccolithophore dynamics in non-bloom conditions during late summer in the central Iceland Basin (July-August 2007). Limnology and Oceanography 55, 1601-1613.

Raitsos, D.E., Lavender, S.J., Pradhan, Y., Tyrrell, T., Reid, P.C., Edwards, M., 2006. Coccolithophore bloom size variation in response to the regional environment of the subarctic North Atlantic. Limnology and Oceanography 51, 2122-2130.

Rees, A.P., Joint, I., Donald, K.M., 1999. Early spring bloom phytoplankton-nutrient dynamics at the Celtic Sea Shelf Edge. Deep-Sea Research Part I - Oceanographic Research Papers 46, 483-510.

Richardson, T.L., Ciotti, Á.M., Cullen, J.J., Villareal, T.A., 1996. Physiological and optical properties of Rhizosolenia formosa (Bacillariophyceae) in the context of open-ocean vertical migration. Journal of Phycology 32, 741-757.

Richardson, T.L., Jackson, G.A., 2007. Small phytoplankton and carbon export from the surface ocean. Science 315, 838-840.

Riegman, R., Stolte, W., Noordeloos, A.A.M., Slezak, D., 2000. Nutrient uptake, and alkaline phosphate (EC 3: 1: 3: 1) activity of Emiliania huxleyi (Prymnesiophyceae) during growth under $\mathrm{N}$ and $\mathrm{P}$ limitation in continuous cultures. Journal of Phycology 36, 87-96.

Rodriguez, F., Varela, M., Fernandez, E., Zapata, M., 2003. Phytoplankton and pigment distributions in an anticyclonic slope water oceanic eddy (SWODDY) in the southern Bay of Biscay. Marine Biology 143, 995-1011.

Schartau, M., Engel, A., Schroter, J., Thoms, S., Volker, C., Wolf-Gladrow, D., 2007. Modelling carbon overconsumption and the formation of extracellular particulate organic carbon. Biogeosciences 4, 433-454.

Schiebel, R., Brupbacher, U., Schmidtko, S., Nausch, G., Waniek, J.J., Thierstein, H.R., 2011. Spring coccolithophore production and dispersion in the temperate eastern North Atlantic Ocean. Journal of Geophysical Research - Oceans 116, 12.

Schlüter, L., Mohlenberg, F., Havskum, H., Larsen, S., 2000. The use of phytoplankton pigments for identifying and quantifying phytoplankton groups in coastal areas: testing the influence of light and nutrients on pigment/chlorophyll a ratios. Marine Ecology - Progress Series 192, 49-63.

Schmidt, S., Harlay, J., Borges, A.V., Groom, S., Delille, B., Roevros, N., Christodoulou, S., Chou, L., in press. Particle export during a bloom of Emiliania huxleyi in the North-West European continental margin. Journal of Marine Systems, http:// dx.doi.org/10.1016/j.jmarsys.2011.12.005.

Seymour, J.R., Simo, R., Ahmed, T., Stocker, R., 2010. Chemoattraction to dimethylsulfoniopropionate throughout the marine microbial food web. Science 329, 342-345.

Sharples, J., Tweddle, J.F., Green, J.A.M., Palmer, M.R., Kim, Y.N., Hickman, A.E., Holligan, P.M., Moore, C.M., Rippeth, T.P., Simpson, J.H., Krivtsov, V., 2007. Spring-neap modulation of internal tide mixing and vertical nitrate fluxes at a shelf edge in summer. Limnology and Oceanography 52, 1735-1747.

Sharples, J., Moore, C.M., Hickman, A.E., Holligan, P.M., Tweddle, J.F., Palmer, M.R., Simpson, J.H., 2009. Internal tidal mixing as a control on continental margin ecosystems. Geophysical Research Letters, 36.

Sherr, E.B., Sherr, B.F. (Eds.), 1993. Preservation and Storage of Samples for Enumeration of Heterotrophic Protists. Lewis Publishers, USA.

Six, C., Thomas, J.C., Brahamsha, B., Lemoine, Y., Partensky, F., 2004. Photophysiology of the marine cyanobacterium Synechococcus sp. WH8102, a new model organism. Aquatic Microbial Ecology 35, 17-29.

Smayda, T.J., 1997. What is a bloom? A commentary. Limnology and Oceanography $42,1132-1136$. 
Smythe-Wright, D., Boswell, S., Kim, Y.N., Kemp, A., 2010. Spatio-temporal changes in the distribution of phytopigments and phytoplanktonic groups at the Porcupine Abyssal Plain (PAP) site. Deep-Sea Research Part II - Topical Studies in Oceanography 57, 1324-1335.

Stefels, J., Steinke, M., Turner, S., Malin, G., Belviso, S., 2007. Environmental constraints on the production and removal of the climatically active gas dimethylsulphide (DMS) and implications for ecosystem modelling. Biogeochemistry 83, 245-275.

Steidinger, K.A., Tangen, K., 1997. Dinoflagellates. In: Tomas, C.R. (Ed.), Identifying Marine Phytoplankton. Academic Press Inc., San Diego, pp. 387-583.

Strom, S.L., Bright, K.J., 2009. Inter-strain differences in nitrogen use by the coccolithophore Emiliania huxleyi, and consequences for predation by a planktonic ciliate. Harmful Algae 8, 811-816.

Sunda, W.G., Huntsman, S.A., 1995. Iron uptake and growth limitation in oceanic and coastal phytoplankton. Marine Chemistry 50, 189-206.

Suykens, K., Delille, B., Chou, L., De Bodt, C., Harlay, J., Borges, A.V., 2010. Dissolved inorganic carbon dynamics and air-sea carbon dioxide fluxes during coccolithophore blooms in the northwest European continental margin (northern Bay of Biscay). Global Biogeochemical Cycles 24, 14.

Throndsen, J., 1997. The planktonic marine flagellates. In: Tomas, C.R. (Ed.), Identifying Marine Phytoplankton. Academic Press Inc., San Diego, pp. 591729 .

Thyssen, M., Garcia, N., Denis, M., 2009. Sub meso scale phytoplankton distribution in the North East Atlantic surface waters determined with an automated flow cytometer. Biogeosciences 6, 569-583.

Tozzi, S., Schofield, O., Falkowski, P., 2004. Historical climate change and ocean turbulence as selective agents for two key phytoplankton functional groups. Marine Ecology - Progress Series 274, 123-132.

Tyrrell, T., Taylor, A.H., 1996. A modelling study of Emiliania huxleyi in the NE Atlantic. Journal of Marine Systems 9, 83-112.

Utermöhl, v.H., 1958. Zur Vervollkommung der quantitative Phytoplankton Methodik. Mitteilungen Internationale Vereinigung für Theoretische und Angewande Limnologie 9, 1-38.

Van Oostende, N., Chou, L., Vyverman, W., Sabbe, K., unpublished-a. Community composition of free-living and particle-associated bacterial assemblages in late spring phytoplankton blooms along the NE Atlantic continental shelf break (northern Bay of Biscay, 2006-2008).
Van Oostende, N., Moerdijk-Poortvliet, T.C.W., Vyverman, W., Boschker, H.T.S. Sabbe, K., unpublished-b. Algal life cycle phase and bacterial activity impact the release of dissolved carbohydrates by Emiliania huxleyi and the formation of transparent exopolymer particles.

Westbroek, P., Brown, C.W., Vanbleijswijk, J., Brownlee, C., Brummer, G.J., Conte, M., Egge, J., Fernandez, E., Jordan, R., Knappertsbusch, M., Stefels, J., Veldhuis, M. Vanderwal, P., Young, J., 1993. A model system approach to biological climate forcing - the example of Emiliania huxleyi. Global and Planetary Change 8, 2746.

Wilson, W.H., Tarran, G., Zubkov, M.V., 2002. Virus dynamics in a coccolithophoredominated bloom in the North Sea. Deep-Sea Research Part II - Topical Studies in Oceanography 49, 2951-2963.

Wood, A.M., Van Valen, L.M., 1990. Paradox lost? On the release of energy-rich compounds by phytoplankton. Marine Microbial Food Webs 4, 103-116.

Wright, S.W., Jeffrey, S.W., Mantoura, R.F.C., Llewellyn, C.A., Bjornland, T., Repeta, D. Welschmeyer, N., 1991. Improved HPLC method for the analysis of chlorophylls and carotenoids from marine-phytoplankton. Marine Ecology - Progress Series 77, 183-196.

Wright, S.W. Jeffrey, S.W. 1997. High-resolution HPLC system for chlorophylls and carotenoids of marine phytoplankton. In: Jeffrey, S.W., Mantoura, R.F.C., Wright, S.W. (Eds.), Phytoplankton Pigments in Oceanography: Guidelines to Modern Methods. UNESCO Publishing.

Zapata, M., Garrido, J.L., 1991. Influence of injection conditions in reversed-phase high-performance liquid-chromatography of chlorophylls and carotenoids. Chromatographia 31, 589-594.

Zapata, M., Jeffrey, S.W., Wright, S.W., Rodriguez, F., Garrido, J.L., Clementson, L., 2004. Photosynthetic pigments in 37 species (65 strains) of Haptophyta: implications for oceanography and chemotaxonomy. Marine Ecology - Progress Series 270, 83-102.

Zhou, J., Mopper, K., Passow, U., 1998. The role of surface-active carbohydrates in the formation of transparent exopolymer particles by bubble adsorption of seawater. Limnology and Oceanography 43, 1860-1871.

Zondervan, I., 2007. The effects of light, macronutrients, trace metals and $\mathrm{CO}_{2}$ on the production of calcium carbonate and organic carbon in coccolithophores - a review. Deep-Sea Research Part II - Topical Studies in Oceanography 54, 521 537. 